\title{
Evolução de Cabeceiras de Drenagem no Médio Vale do Rio Paraíba do Sul (SP/RJ): a Formação e o Crescimento da Rede de Canais sob Controle Estrutural
}

\author{
Ana Luiza Coelho Netto ${ }^{(1)}$. \\ (1) Professora Titular, Depto. de Geografia/IGEO-UFRJ; Pesquisadora 1-B/CNPq; \\ Coord. do GEOHECO/Laboratório de Geo-Hidroecologia; \\ e-mail: ananetto@acd.ufri.br .
}

\section{Resumo}

Este artigo apresenta os resultados das pesquisas conduzidas no médio vale do rio Paraíba do Sul, na bacia do rio Bananal (518 $\mathrm{Km}{ }^{\jmath}$ e adjacências, sobre a formação e crescimento de redes de canais em cabeceiras de drenagem e suas implicações no rebaixamento diferencial dos divisores de bacias de drenagem sob forte controle estrutural. A ênfase recai nas interações geológico-geomorfológicas que regulam a geração de fluxos ascendentes em fraturas subverticais (artesianismo) e suas relações com a formação dos regolitos. As discussões focalizam a natureza dos processos geomorfológicos responsáveis por: 1- formação de depressões fechadas em divisores e suas relações com a origem de concavidades estruturais; 2- origem e progressão de canais incisos (tipo voçoroca) através das cabeceiras de drenagem; 3- relação entre a incisão linear (ou rebaixamento de nível de base) e o recuo dos divisores; 4- - interações hidrológica e erosiva em cabeceiras de drenagem adjacentes; 5- interações hidrológica e erosiva entre vales fluviais adjacentes e topograficamente desnivelados. Os dados revelam que a rede é dominada pelo crescimento regressivo dos canais de primeira ordem sobre os vales de cabeceiras, onde outros canais menores podem se desenvolver e originar vales suspensos próximos aos divisores, bem como que com a progressão da incisão linear dos canais e rebaixamento do nível freático, acentua-se a competição pela água subterrânea entre vales de cabeceiras ou vales fluviais adjacentes, limitando a geração de fluxos artesianos e os desenvolvimentos da rede de canais interconectados, corroborando o preconizado pela Lei de Gilbert (1877).

Palavras chave: fratura, artesianismo,voçoroca, deslizamento, recuo de divisor.

\begin{abstract}
In this paper I review our researches carried out in the middle Paraíba do Sul river valley with my students and colleagues. The main field-laboratory is the Bananal river basin $\left(518 \mathrm{~km}^{2}\right)$ and surrounds. The main focus is driven toward to structurally controlled channel formation and network growth in valley heads and their implications on differential slope retreat and lowering slope divides. Special attention is given to the role of geologic-geomorphological interactions in controlling artesian flows through subvertical joints and their relationships with regolith development. Discussions are focusing on the nature of geomorphic processes which are responsible for: 1- origin of closed depressions on hillslope divides and their relationships with the formation of structurally controlled valley heads or topographic hollows; 2-origin and progression of incised channels (or gullies) by the action of groundwater flows in topographic hollows; 3- relationships between channel incision (or lowering base level) and backward retreating of slope divides; 4- hydrologic and erosive interactions in adjacent hollows and, 5-hydrologic and erosive interactions in adjacent river valleys which are not topographically adjusted to the same base level control. In the studied drainage basin the regressive channel network growth prevail throughout the valley axis of topographic hollows; minor channels may also develop in separate nearby the slope divides giving origin to hanging topographic hollows. Channel incision and lowering local water table provide a competition for ground water aquifer among adjacent valley heads so that less competitive
\end{abstract}


hollows are left at hanging and erosion tend to stabilize. On the other hand, the more effective is the valley incision, the surrounding slopes will tend to become unstable and landslides will tend to provide for slope retreating and lowering the divides. Retreating of slope divides can be favored by groundwater piracy, particularly between adjacent valley heads or river valley bottons under different elevations; channel retreating from the lower valley botton can advance through the slope divides as groundwater piracy provide an increasing discharge in the seepage face. So that the captured valley will tend to degrade until a new slope profile is adjusted to the lower capturing channel network, as it might be expected according to the Law of Gilbert (1877).

Key Words : fracture, artesianism, gully, slump, regressionof divides

\section{Introdução}

As cabeceiras de drenagem desenvolvem-se no domínio das encostas e apresentam topografia côncava sobre as quais se originam ou avançam as cabeças de canais. O termo "cabeceira de drenagem" é tratado na literatura internacional como "hollow" (Hack, 1960) e no Brasil de "rampa" (Meis \& Monteiro, 1979) ou "concavidade" (Avelar \& Coelho Netto, 1992a e 1992b). O termo "cabeça de canal" refere-se às extremidades de montante dos canais erosivos que avançam progressivamente através dos fundos de vales das cabeceiras de drenagem e correspondem ao "channel head" de Dietrich \& Dunne (1993) ou "stream head" (Kirkby, 1994). Os canais erosivos das cabeceiras de drenagem drenam através da rede principal de canais fluviais, integrando os processos de encostas com os processos fluviais. Assim a rede interconectada de canais fluviais constitui-se na principal via de descarga da bacia de drenagem e, por isso, tornou-se um dos principais objetos de grande interesse hidrológico e geomorfológico, especialmente a partir de Horton (1945)

É reconhecido o fato de que, numa rede de canais, metade das bifurcações de canais são externas, ou seja, de canais de primeira ordem, seguindo a lei de número de canais de Horton (1933). Ahnert (1998) ressalta que a cabeceira de drenagem é um componente especial do sistema fluvial, porque é uma área onde a transição dos processos de denudação para transporte erosivo é caracterizada pela convergência em direção à porção terminal da rede de canais.

Três modelos determinísticos tornaram-se bastante conhecidos para explicar o desenvolvimento das redes de canais. No primeiro, proposto por Glock (1931), prevaleceria seu alongamento na subdividisão das áreas de drenagem não dissecadas; a extensão da rede se daria pelo avanço remontante dos canais ou pela adição de canais que se originam em separado, até atingir uma extensão máxima sobre toda área de drenagem disponível. Com o rebaixamento dos divisores e conseqüente redução do relevo, alguns canais desapareceriam o que o autor chamou de processo de absorção; e com a migração lateral dos canais principais, outros pequenos canais tributários também desapareceriam pelo processo então denominado de abstração. Assim, num estágio mais avançado do desenvolvimento da rede, a densidade de drenagem diminuiria.

Horton (1945) propôs um segundo modelo por ação do escoamento superficial em áreas íngremes e planas, onde uma série de sulcos erosivos paralelos se formariam a partir de uma distância crítica dos divisores $(\mathrm{x})$. Com o tempo, o ajuste lateral e a micropirataria de águas superficiais entre sulcos erosivos adjacentes acarretaria competição e aprofundamento dos sulcos de maior concentração de escoamento superficial originando canais incisos (chamados na literatura internacional de "gully "). Progressivamente, estes se tornariam mais capazes de absorver seus competidores, por gradação lateral, propiciando a expansão de redes de canais integradas e dendríticas. Neste modelo hortoniano, a extensão máxima do canal dominante não ultrapassaria a distância crítica dos divisores $\left(\mathrm{x}_{\mathrm{c}}\right)$, constituindo-se uma zona não-erosiva próxima aos divisores.

Um terceiro modelo foi proposto por Howard (1971), com base apenas no crescimento remontante dos canais, onde a rede se desenvolveria plenamente até a borda da área não-dissecada, segundo o qual, na medida em que os canais progridem remontantemente e bifurcam, eles ocupam os espaços disponíveis e formam uma rede dendrítica. Seguindo este modelo, Dunne (1970, 1980), propôs que, em regiões úmidas, a formação e o crescimento de redes de canais resulta de mecanismos erosivos por excesso de poro-pressão em faces de exfiltração da água subterrânea (ou "headward spring sapping"), onde as fraturas das rochas subjacentes podem influenciar o traçado das rotas preferenciais de crescimento da rede. Como Horton (1945), ele sugeriu que o avanço remontante dos canais tenderia a estabilizar numa certa distância crítica dos divisores, em função da redução progressiva da área de contribuição dos fluxos d'água subterrâneos que 
convergem para a cabeça do canal erosivo, limitando a geração de descargas críticas na face de exfiltração.

Nas últimas décadas é notório o aumento dos estudos voltados à modelagem física e matemática sobre expansão da rede de canais, com atenção especial sobre a localização das cabeças de canais, ou seja, aonde inicia os canais nas cabeceiras drenagem. Segundo Kirkby (1994) esta modelagem é relevante tanto na explicação da variação dos padrões espaciais estáticos das redes de canais como também na avaliação da vulnerabilidade potencial dessas áreas para uso da terra ou para avaliar os efeitos das mudanças climáticas globais. Ele sugere que o espaçamento entre canais de cabeceiras de drenagem parece estar relacionado, ao menos em parte, com o balanço entre os processos de encosta e, no canal, com o transporte de água e sedimentos; trata-se, portanto, de uma feição morfológica que se relaciona com a magnitude e freqüência dos eventos climáticos, especialmente os pluviométricos.

Kirkby (1994) destaca que, seguindo o contexto acima, sob regime semi-árido, prevaleceriam curtos espaços entre os canais, associados à escassez de vegetação e altas taxas de escoamento superficial e de perdas de sedimentos, tal como nas chamadas badlands. Em áreas temperadas úmidas a densidade de canais tenderia a ser mais baixa em associação com os mantos de solos mais espessos e cobertura vegetal. Contudo, ele ressalta que estudos empíricos indicam que a densidade de canais em cabeceiras de drenagem não necessariamente depende de variáveis causais externas como capacidade de infiltração, reflexo da cobertura superficial ou das características físicas das chuvas. De fato, estudos conduzidos em área temperada úmida na costa oeste norte-americana entre os estados da Califórnia e de Washington (Dietrich et al (1986); Montgomery e Dietrich, 1988; Dietrich e Dunne, 1993) mostraram uma dependência inversa entre a área que converge para as cabeças de canais (então chamadas de "source-area") e o gradiente topográfico do vale.

Motivados por esses estudos interessou-nos testar esse modelo no domínio de colinas rebaixadas da bacia do rio Bananal ( $\mathrm{RJ} / \mathrm{SP})$, dada a sua semelhança com algumas das cabeceiras californianas, especialmente de Briones, costa Pacífica, próximo à Baía de São Francisco. O estudo das cabeceiras de drenagem suspensas foi priorizado por serem as que melhor se aproximam dos chamados "bedrock hollows" descritos e investigados pela equipe de W.E.Dietrich.

Surpreendentemente os 51 casos levantados segundo os mesmos critérios aplicados na costa oeste norte-americana, não mostraram dependência entre a localização das cabeças de canais e o tamanho da área ou com o gradiente topográfico da cabeceira de drenagem. Ao contrário, algumas se desenvolvem muito próximas ao divisor de águas, levando a questionar o conceito de zona não-erosiva a partir de uma distância crítica dos divisores de águas $\left(\mathrm{x}_{\mathrm{c}}\right)$ (Horton, 1945 e Dunne, 1980).

Frente ao exposto, apresenta-se neste trabalho uma revisão dos resultados das pesquisas sobre formação e propagação de rede de canais em cabeceiras de drenagem, sob forte controle litoestrutural e clima tropical úmido, que vem sendo conduzidas no médio vale do rio Paraíba do Sul. As áreas-laboratórios de campo concentram-se na bacia do rio Bananal $\left(518 \mathrm{~km}^{2}\right)$ que drena da serra da Bocaina (no município de Bananal, SP) para o rio Paraíba do Sul (no município de Barra Mansa, RJ) (Figura 1), focalizando os elementos estruturais e funcionais que regulam a rota dos fluxos d'água subterrâneos e a variação espacial dos processos

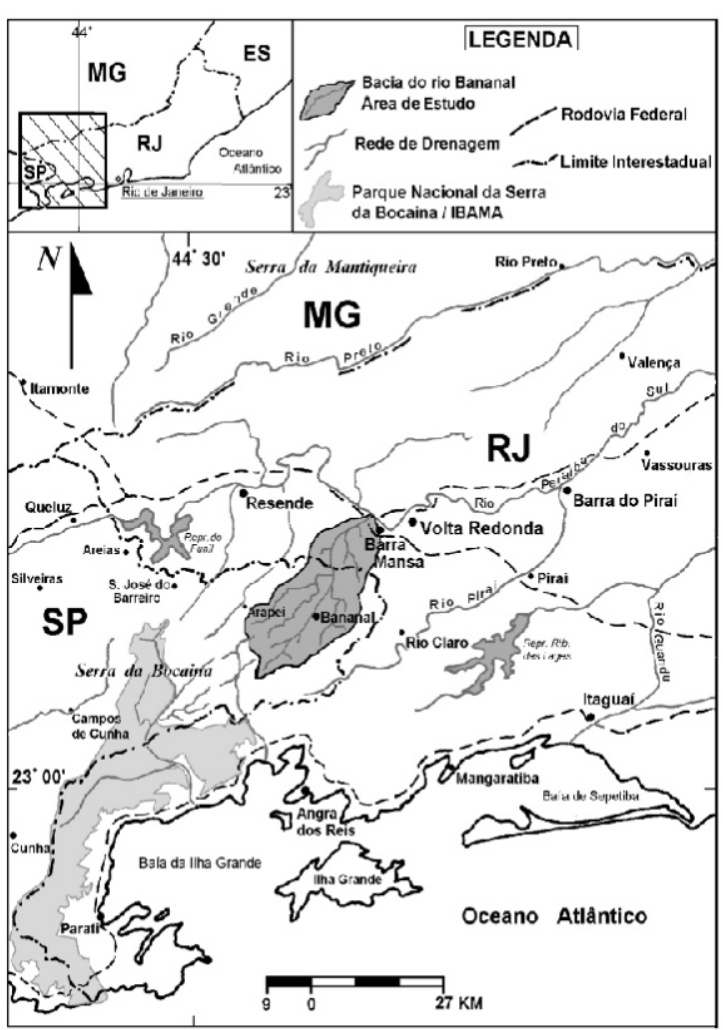

Figura 1 - Localização da bacia do rio Bananal e adjacências, no médio vale do rio Paraíba do Sul, na fronteira entre os estados de São Paulo e Rio de Janeiro.

geomorfológicos, de formação e crescimento de redes de canais e evolução das cabeceiras de drenagem.

\section{O Médio Vale do Rio Paraíba do Sul: Estruturas Relevantes}

A área estudada drena parte do médio vale do rio Paraíba do Sul, próximo ao paralelo de $23^{\circ} \mathrm{S}$, e 
insere-se no Planalto Sudeste Brasileiro, na porção central da Faixa Móvel Ribeira, ao sul do cráton de São Francisco (Figura 1).

Compreende quatro compartimentos tectônicos com orientação dominante NE-SW: um autóctone e três alóctones, descritos por Heilbron (1995): o ciclo orogênico Brasiliano (NeoProterozóico e Cambro-Ordoviciano) marcado por forças compressivas e dúcteis responsáveis pela formação do cinturão móvel; dois ciclos marcados por forças extensivas e rúpteis, relacionados à abertura Atlântica das margens passivas (iniciada no Jurássico) e o "rifting" continental de idades neocretácea e paleogênica..

Os compartimentos tectônicos descritos incluem três grupos litológicos: o embasamento, de idade pré-1.8 G.a.; as rochas supra-crustais pós-1.8 G.a.e as rochas granitóides pós-tectônica Brasiliano e colisionais. A principal estrutura tectônica herdada deste tempo mais antigo é a megasinformal do Paraíba do Sul. A tectônica cretácea-paleogênica foi responsável pelo sistema de rifteamento do sudeste brasileiro, caracterizado por uma série de falhamentos rúpteis e subverticais. Falhas normais com orientação ENE e mergulhos para SE definem o limite dos blocos norte das bacias sedimentares Cenozóica (bacias de Resende e Volta Redonda). As falhas transcorrentes são orientadas no sentido NW-NNW; a zona transtensional de Volta Redonda, orientada no sentido NW-S é uma feição regional marcante e relativa a estes eventos. Trata-se de uma zona de transferência que conectou os "rifts" do Paraíba e da Guanabara, deslocando o eixo da megasinformal do Paraíba, como foi sugerida por Valeriano e Heilbron (1993). Estes eventos também foram responsáveis pela propagação regional de dois conjuntos principais de fraturas subverticais orientadas para NE-SW e NW-SE (Figura 2).

As falhas normais promoveram soerguimentos e subsidências diferenciais, assim como a exumação de blocos crustais. Desde então, a renovação do relevo marcada pelo rebaixamento regional dos níveis de base e suas estruturas subjacentes, têm influenciado a evolução do sistema regional de drenagem. O curso médio do rio Paraíba do Sul corre, em sua maior parte, ao longo do "graben" da principal falha normal (ENE), mudando o seu curso para NW-SE, entre Floriano e Barra Mansa, onde corre sobre a zona transtensional de Volta Redonda. As bacias aqui focalizadas seguem as estruturas geológicas herdadas desde o tempo mais antigo e, principalmente, da última fase orogênica do Cenozóico: as bacias do rio Bananal e do rio Barreiro de Baixo, que drenam para NE, no reverso da escarpa da falha Atlântica, localmente denominada Serra da Bocaina e relaciona-se às direções estruturas regionais.

O rio Bananal, em seu baixo curso, corre paralelo ao eixo da megasinformal do Paraíba,

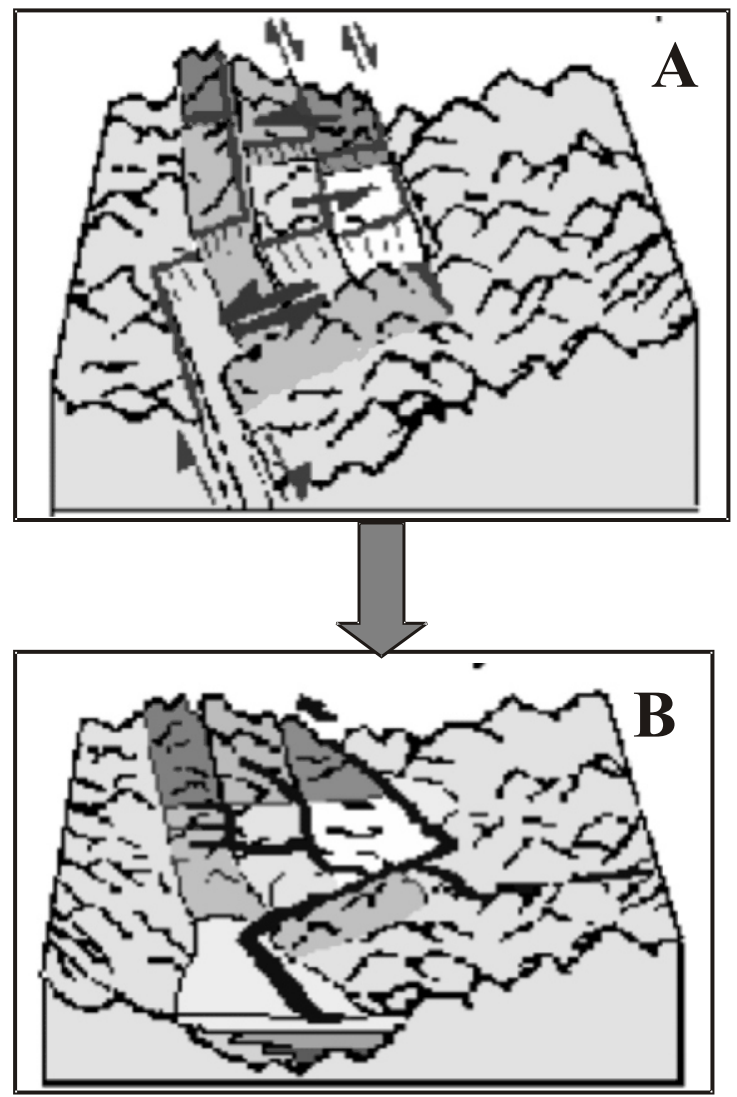

Figura 2 - Representação esquemática: (A)- sistema de falhas normais e transcorrentes associadas à abertura do Atlântico e ao "rifting" continental, evidenciando o rebaixamento regional dos níveis de base; (B)- atual rede de canais principais superpostas as estrutura da zona de transferência de Volta Redonda: o rio Paraíba ao centro; a direita o rio Bananal e no perfil frontal, a bacia de Resende.

entalhando uma falha normal ENE de idade Cenozóica. A montante, o canal segue o falhamento NW-NNW de mesma idade e, no seu médio-alto curso segue em paralelo à orientação das camadas geológicas de idade pré-cambriana, no sentido SW$\mathrm{NE}$, aprofundando o seu leito nas camadas menos resistentes. Os seus tributários principais também têm aprofundado seus leitos ao longo das camadas rochosas menos resistentes (ex: rio Piracema) ou em paralelo aos falhamentos NW-NNW (ex: rio Carioca) (Figura 3).

O rio Barreiro de Baixo, em seu baixo curso, segue em paralelo aos falhamentos NW-NNW, desviando o seu médio-alto curso para correr em paralelo ao rio Bananal, ou seja, em paralelo à orientação SW-NE das camadas geológicas subjacentes.

Mas, grande parte do seu curso segue em 


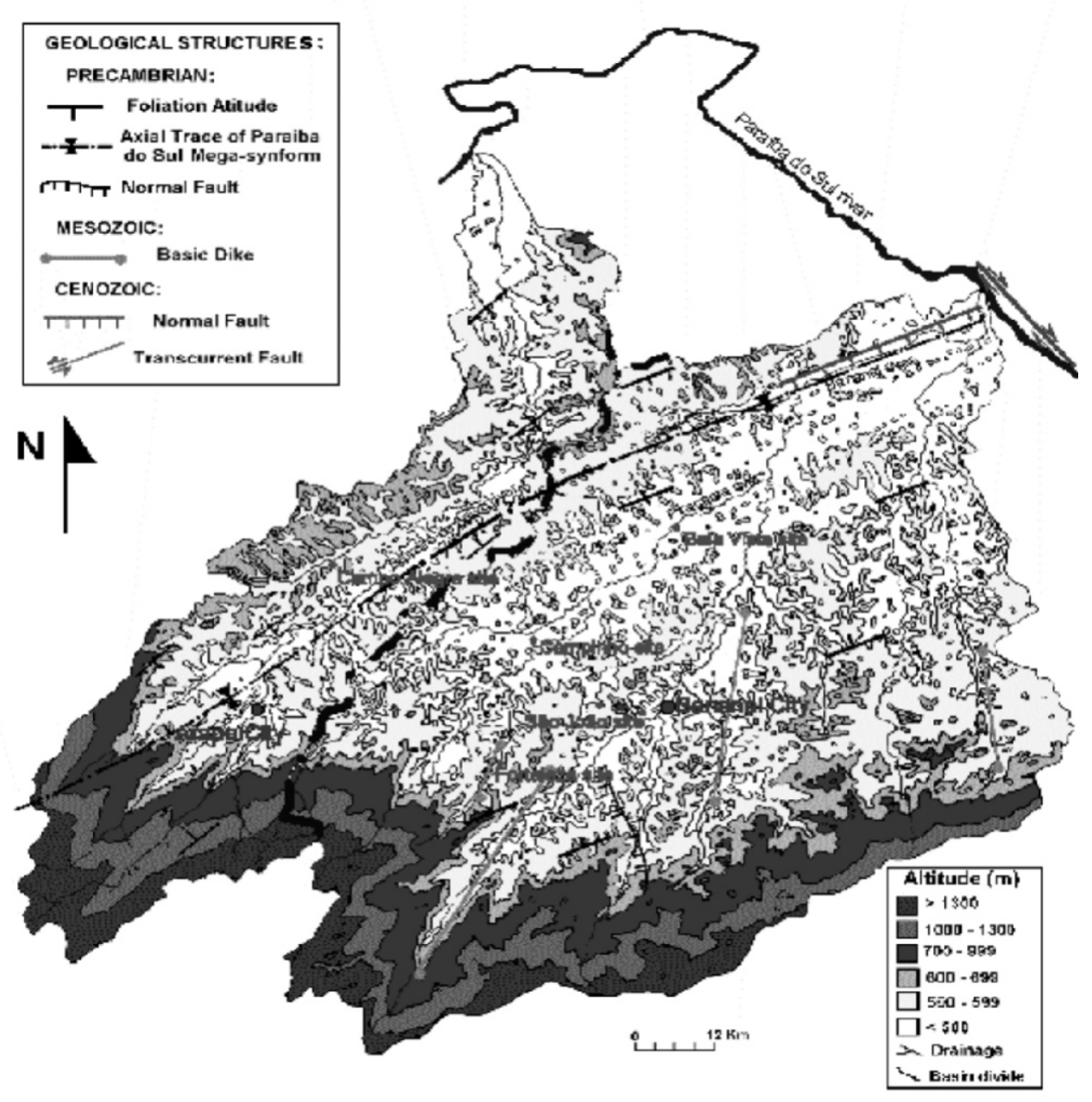

Figura 3 - Hipsometria e principais estruturas geológicas nas bacias dos rios Bananal e Barreiro de Baixo.

paralelo ao eixo da megasinformal do Paraíba e seu eixo principal desenvolveu-se sobre a zona de cisalhamento de Arapeí, onde as camadas geológicas mergulham subverticalmente, prevalecendo formas de valessimétricos.

A vertente esquerda desta bacia apresenta um nível altimétrico mais elevado do que a vertente direita, que faz divisa com a bacia do rio Bananal, apresentando, portanto, gradientes topográfico e hidráulico relativamente mais elevados.

\section{A Bacia do Rio Bananal}

O rio Bananal disseca o compartimento superior da Faixa Ribeira, composto por rochas de alto grau metamórfico, de idade Pré-Cambriana, incluindo: o embasamento de idade pré-1.8 G.a. (ortognaisses); a seqüência meta-sedimentar do Grupo Paraíba do Sul e as rochas granitóides, com "strikes" de direção NE-SW e mergulho de $20^{\circ}$ a 40 NW (Silva et al, 1994; Almeida et al, 1991,1993). Esses autores identificaram três unidades litológicas principais, da base para o topo: Unidade Três Barras- biotita-gnaisse bandado, com lentes de rochas cálcio-silicáticas e xistos pelíticos; Unidade São João- sílica-granadamuscovita-biotita gnaisse com níveis de gondito, rochas cálcio-silicáticas, xistos pelíticos e mármore e Unidade Beleza- biotita gnaisse bandado, com várias intercalações de rochas cálcio-silicáticas, xistos pelíticos, gondito, mármore e quartzito. As rochas granitóides foram subdivididas em cinco unidades principais: Rio Turvo (granito porfirítico/biotita gnaisse); Serra da Bocaina (hornblenda-biotita gnaisse); Resgate (turmalina-biotita-muscovita-xistoquartzo gnaisse); Campinho (biotita-hornblenda gnaisse) e Taquaral (granodiorito biotita-hornblenda gnaisse e granito leucocrático). (Figura 4).

A bacia do rio Bananal apresenta dois compartimentos topográficos principais: um montanhoso, com mais de $700 \mathrm{~m}$ de desnível e um outro inferior, a 200m (Fernandes, 1991). No compartimento montanhoso predominam as encostas retilíneas e fundos de vales estreitos; no compartimento rebaixado prevalecem as colinas convexo-côncavas e fundos de vales largos, 


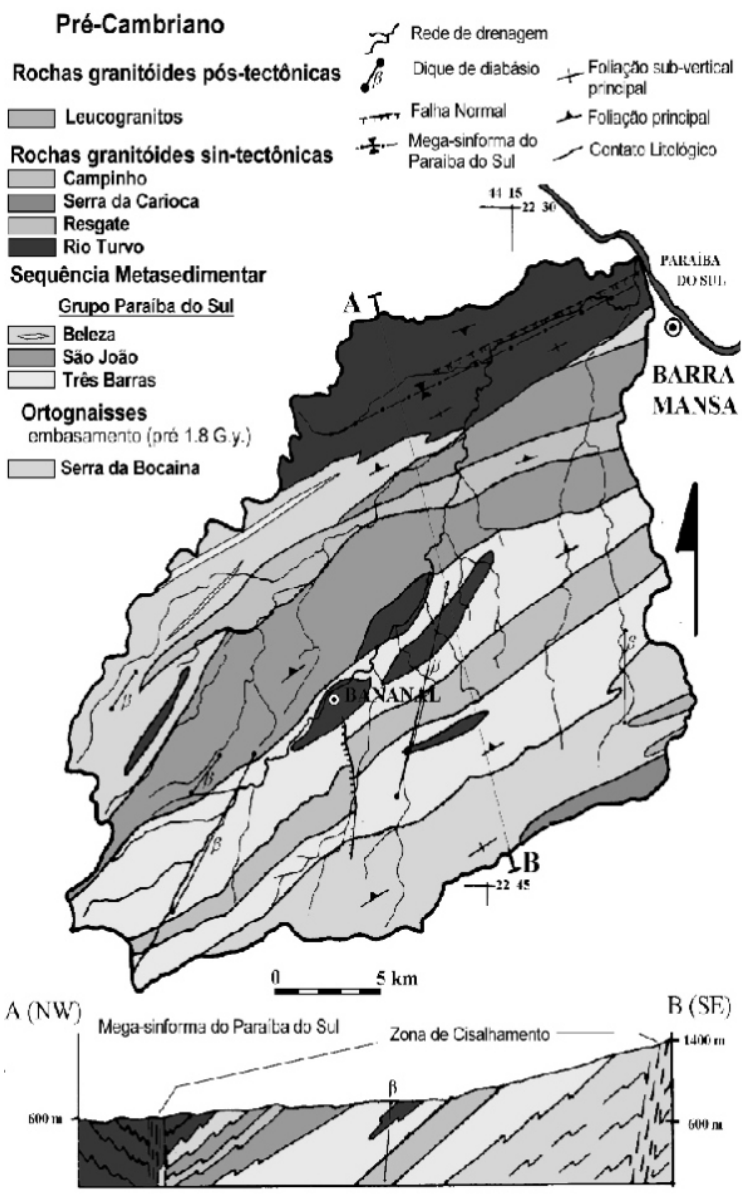

Figura 4 - Mapa Geológico-Estrutural da bacia do rio Bananal e perfil geo-transversal (A-B), Silva et al. (1994).

suavemente inclinados. Ao longo dos canais principais ocorrem diversos níveis de base rochosos, compondo cachoeiras e rápidos com alturas que podem variar de poucos metros a mais de 30 metros, nos dois compartimentos topográficos, configurando uma bacia escalonada com vales suspensos que operam independentes do sistema regional de canais topograficamente ajustados ao rio Paraíba do Sul. Dantas e Coelho Neto (1994) observaram que nas imediações desses níveis de base rochosos, o fundo de vale estreita-se e, a montante, alarga-se, formando amplos alvéolos onde a sedimentação fluvial espraiase e torna-se menos espessa $(<10 \mathrm{~m}$ de altura).

Evidências estratigráficas e numerosas datações absolutas nos pacotes de sedimentos fluviais e de encostas demonstram a ocorrência de dois ciclos recentes de instabilidade morfodinâmica, sincronizados na escala de bacia do rio Bananal (Dietrich et al., 1991; Coelho Netto et al., 1994; Coelho Netto, 1999). O primeiro ciclo erosivo-

\footnotetext{
${ }^{1}$ Estudos de pólen realizados em sedimentos fluviais da bacia do rio Bananal por Aguiar at al (1999) e Aguiar (2003), indicam que por volta de 9000 anos A.P. ainda prevalecia uma vegetação de gramíneas com árvores esparsas (tipo
}

deposicional ocorreu entre 10.000 e 8.000 anos atrás, na transição Pleistoceno-Holoceno, induzido por alterações paleoambientais e hidrológicas associadas às mudanças climáticas decorrentes do aquecimento global. O outro ciclo, iniciado há 200 anos atrás, foi induzido pela devastação da Floresta Atlântica original, em decorrência da expansão regional do ciclo cafeeiro (entre meados do século XVIII e final do século XIX), seguindo pela atividade de pecuária extensiva (domínio de gramíneas) até a metade do século XX, a partir do qual se intensificou a atividade industrial e a expansão dos núcleos urbanos.

Hoje, prevalece uma paisagem heterogênea e instável submetida a mudanças ambientais cada vez mais rápidas e sob altas taxas de erosão e deposição nas encostas e fundos de vales fluviais; enquanto nos domínios montanhosos prevalecem os deslizamentos, nos domínios de colinas, sob espessa sedimentação quaternária, prevalecem os mecanismos de erosão linear. A progressão na incisão e/ou recuo desses canais erosivos tende a favorecer a ocorrência de deslizamentos, particularmente junto às encostas mais íngremes, e sua intensificação nas cabeceiras de drenagem vem acarretando um aumento das taxas de assoreamento nos canais fluviais coletores e aumento das enchentes nas planícies de inundação.

A precipitação média anual é da ordem de $2000 \mathrm{~mm}$ no domínio montanhoso, e de $1200 \mathrm{~mm}$ no domínio das colinas, com verões geralmente mais chuvosos. Entretanto, Figueiró et al (2003), com base em longa série de registros pluviométricos da Estação Resende, apontam alterações nos regimes de chuvas ao longo do século $\mathrm{XX}$, que potencializariam a instabilidade das encostas, a saber: (a) decréscimo das chuvas anuais, como observado por Meis et al (1981), sobre outra série de registros; (b) aumento na freqüência dos meses menos chuvosos, com totais inferiores a $100 \mathrm{~mm}$ e aumento na irregularidade do regime de distribuição das chuvas mensais; c) aumento na freqüência e intensidade das chuvas diárias superiores a $100 \mathrm{~mm} /$ dia, especialmente no alto verão.

\section{As Cabeceiras de Drenagem da Bacia do Rio Bananal}

As cabeceiras de drenagem têm em comum a topografia côncava (para cima), no entanto podem variar em suas características morfológicas, tamanho, profundidade e declividade. Podem ser unidades simples ou podem conter uma ou mais concavidades menores que convergem e alimentam a concavidade principal. Meis \& Monteiro (1979) ao denominarem essas unidades côncavas simples de rampas, incluiram a feição erosiva na porção superior e uma feição deposicional na porção médio-inferior, com

Cerrado), já mostrando evidências de uma evolução para a Floresta Tropical Úmida no início do Holoceno. 
espessamento dos depósitos em direção ao eixo inferior das concavidades; segundo as autoras, sucessivas fases de reafeiçoamento das rampas e o retrabalhamento dos depósitos originaram os chamados complexos derampas.

Das concavidades menores dos complexos de rampas convergem quantidades residuais de sedimentos coluviais que podem ser, pelo menos em parte, retrabalhados ao longo do eixo da concavidade principal, originando os chamados depósitos alúviocoluviais no fundo do vale-tronco da cabeceira de drenagem; estes vales também são denominados anfiteatros. $\mathrm{Na}$ transição entre a sedimentação de encostas e a sedimentação fluvial, os colúvios e alúvio-colúvios tendem a sobrepor e interdigitar com os depósitos dos rios principais, configurando as chamadas rampa-terraços definidas por Machado \& Moura (1982). Meis e Moura (1984), Moura e Meis (1986), Moura (1991) e Mello (1992) descreveram a estratigrafia desses depósitos quaternários na bacia do rio Bananal.

\section{1 - Tipologia de Cabeceiras ou Conca-} vidades Topográficas

Algumas nomenclaturas têm sido propostas para classificar a morfologia das cabeceiras de drenagem na área, incluindo a de Moura et al. (1991). Neste artigo optou-se por incorporar a forma geométrica dominante nos vales de cabeceiras, ou seja, topograficamente côncava para cima, adotando o conceito original de "hollow" proposto por Hack (1961), baseando-se na classificação morfológica das concavidades topográficas (tradução direta do termo "hollow"), incluindo dois tipos principais:

1. A Concavidade Aberta (CA), é larga na base inferior, apresenta um fundo de vale raso e com eixo longitudinal curto e, em geral, é topograficamente nivelada (ou ajustada) com o fundo de vale fluvial adjacente; a convexidade na borda externa da concavidade, assim como a suavização nas mudanças internas de declives indicam uma condição local de estabilidade durante, pelo menos, alguns poucos milhares de anos (Figura 5-a). No estágio inicial de sua esculturação, essas formas são instáveis e apresentam arestas agudas no seu contorno, visíveis onde deslizamentos associados ao descalçamento da base de encostas (por ação erosiva de canais fluviais ou por cortes de estrada) propiciam a formação inicial deste tipo de concavidade.

2. A Concavidade Estrutural (CE) é larga na porção superior e estreita na base inferior; associa-se ao forte controle das estruturas geológicas subjacentes sobre os processos geomorfológicos responsáveis por sua origem e evolução(Avelar e Coelho Netto 1992).

O eixo longitudinal do fundo de vale de cabeceira apresenta extensão variável e pode estar topograficamente ajustado ao fundo de vale fluvial principal, sendo denominada Concavidade Estrutural

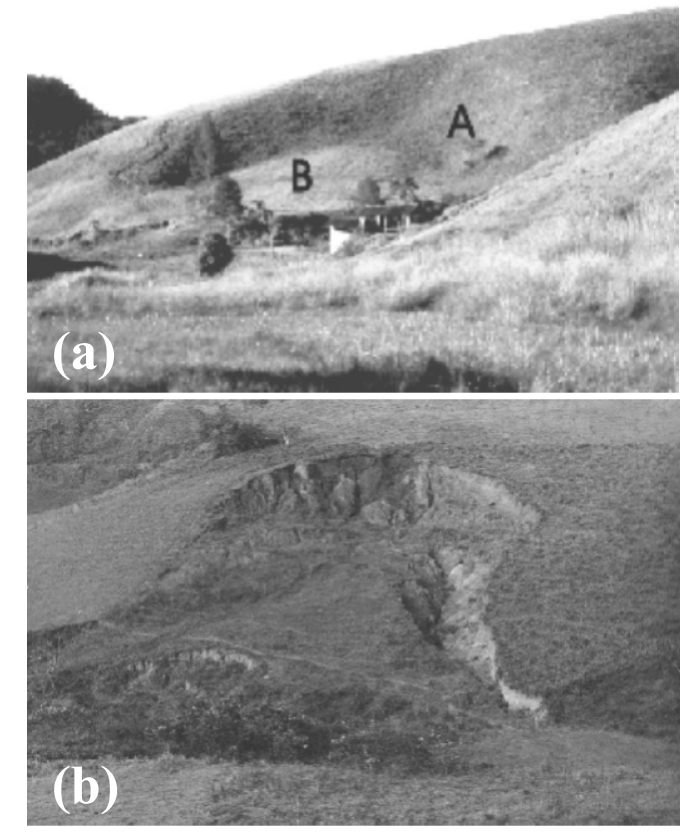

Figura 5 - Concavidade Aberta topograficamente ajustada com o vale fluvial adjacente: (a) concavidade mais antiga e estável onde Afeição erosiva e B- feição deposicional; (b) concavidade em formação inicial, instável e sob retrabalhamento e reafeiçoamento.

Ajustada; ou pode estar topograficamente suspenso, constituindo-se numa Concavidade Estrutural Suspensa. Estas últimas formam-se próximas aos divisores de águas (Figura 6).

A Figura 6-a ilustra uma seqüência lateral de CE-Suspensas (CES), estáveis e com espaçamentos regulares entre si, ou seja, entre os respectivos eixos longitudinais suspensos; a jusante desses fundos de vales suspensos, iniciam-se canais incisos na rocha, encaixados em fraturas subverticais, os quais drenam para o alto curso do córrego Fortaleza, cujo vale fluvial também é fortemente encaixado; situam-se na vertente direita, que acompanha o mergulho das camadas geológicas subjacentes (Unidade São João). Merece destaque o aprofundamento diferencial dessas concavidades, aumentando para jusante. A seta preta no interior da segunda CES, da esquerda para direita, destaca a formação de uma sub-CES.

A Figura 6-b ilustra uma CE-Ajustada (CEA), no domínio de colinas rebaixadas próximo da localidade Bom Jardim, na cidade de Bananal; o fundo de vale foi topograficamente nivelado com o leito do rio Bananal através da expansão remontante de um canal inciso por mecanismos erosivos acionados pela exfiltração de água subterrânea (voçorocamento), o qual recuou até a base da encosta traseira; na parte superior desta encosta, observa-se a formação de uma sub-CES, indicada pela seta preta; a jusante do eixo 
desta sub-concavidade suspensa desenvolve-se um sistema de canais descontínuos associados a processos de erosão em túnel ao longo de fraturas subverticais, ainda preservadas no saprolito de rochas granitóides (Granitóide Rio Turvo).
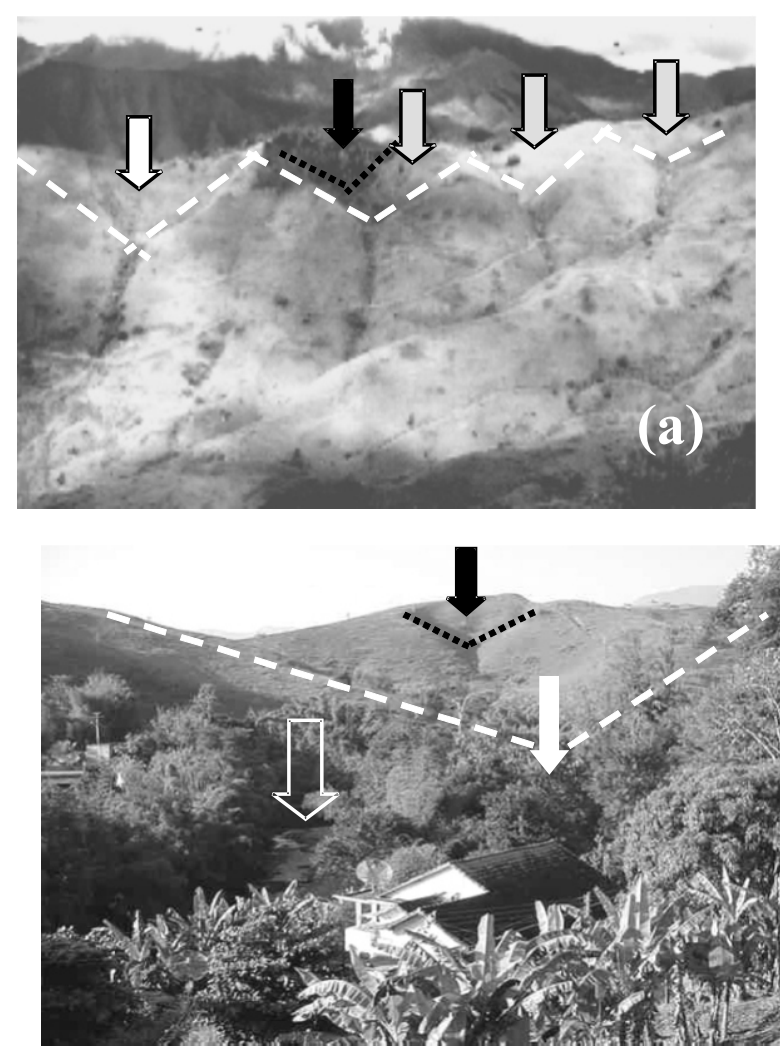

Figura 6 - Fotos ilustrando o tipo de Concavidade Aberta topograficamente ajustada com o vale fluvial adjacente: (a) concavidade mais antiga e estável; A- feição erosiva e B- feição deposicional; (b) concavidade em formação inicial, instável e sob retrabalhamento e reafeiçoamento.

\section{Topográficas}

\section{2- Padrões Espaciais das Concavidades}

Avelar e Coelho Netto (1992) avaliaram os padrões espaciais de distribuição das concavidades abertas e estruturais, no compartimento de colinas da bacia do rio Bananal, sob diferentes litologias e densidades de fraturas subverticais, e observaram que o percentual de concavidades é inferior ao valor regional (29\%) apontado por Oliveira e Meis (1985), variando localmente em associação com as condições lito-estruturais subjacentes. Por exemplo, na localidade Bom Jardim, situada no médio vale do rio Bananal, sobre um substrato rochoso mais homogêneo (granitóide Rio Turvo) e menor densidade de fraturas $\left(0,76 \times 10^{-6} / \mathrm{m}^{2}\right)$ as concavidades representam apenas $15 \%$ da área total considerada $\left(15 \mathrm{~km}^{2}\right)$; já na localidade Três Barras, também no médio vale do rio Bananal, sobre o gnaisse bandado e heterogêneo (unidade Três Barras), com alta densidade de fraturas $\left(1,82 \times 10^{-6} \mathrm{~m}\right)^{2}$, as concavidades ocupam apenas $18 \%$ da área total considerada $(15 \mathrm{~km})$.

Os autores ainda indicaram que as concavidades estruturais predominam em todas as litologias estudadas, independentemente das variações de densidades de fraturas. Dentre essas concavidades estruturais, predominam as ajustadas à rede regional de canais (tipo CEA). No entanto, já a proporção de concavidades do tipo CES varia entre as litologias: são mais freqüentes na localidade Bom Jardim (31\%) e menos freqüentes na localidade Três Barras. Este fato alimentou a hipótese de que a denudação estaria sendo mais eficiente em áreas mais fraturadas, favorecendo o ajuste de declives entre concavidades originalmente do tipo CES, com as concavidades adjacentes do tipo CEA, o que reduziria a freqüência destas, tal como previsto pela Lei do Ajuste de Declives de Gilbert (1877).

$\mathrm{Na}$ escala da bacia principal, através do histograma de densidade de concavidades por setores do alto, médio, médio-baixo e baixo vale do rio Bananal, ressalta-se a variação espacial da densidade de todos os tipos de concavidades no contexto da bacia, sendo menor na porção superior do vale. As concavidades estruturais dominam em todos os setores da bacia, prevalecendo o tipo CEA e dentre elas as ajustadas sem incisão de canais relacionadas aos fundos de vales de cabeceiras de drenagem entulhada pelos espessos pacotes de sedimentos quaternários (colúvios e alúvio-colúvios)

Para jusante da bacia há um aumento progressivo da densidade de concavidades estruturais, evidenciando que as suas características físicas, como um todo, exercem um controle sobre a magnitude diferencial dos processos de denudação nas cabeceiras de drenagem. Por outro lado, a redução progressiva da densidade de concavidades abertas, nessa mesma direção, reflete um padrão de variação espacial dos controles internos do sistema, que as potencializam, como corte de estrada e solapamento erosivo de rios adjacentes às encostas mais íngremes, influência essa reduzida no vale médio-inferior e inferior, porque os fundos de vales fluviais tornam-se relativamente mais largos, reduzindo o impacto erosivo dos rios sobre encostas laterais; e as estradas maiores são menos densas no baixo vale. (Figura 7). 


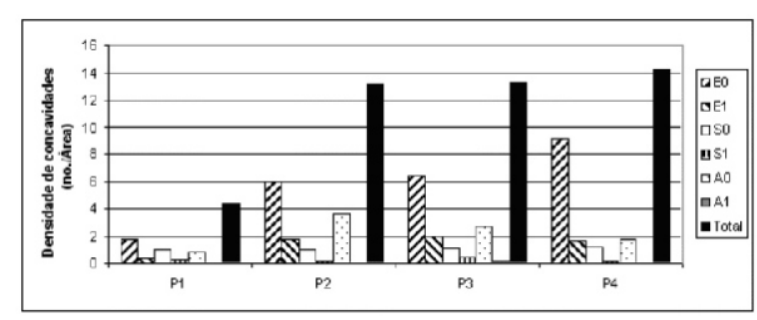

Figura 7: Histogramas de densidade de concavidades (Dc $=\mathbf{N}^{\mathbf{0}}$ de concavidades/Área total do setor da bacia) no vale do rio Piracema; setores da bacia: P1-alto vale; P2-médio vale; P3-médio-baixo vale e P4-baixo vale; tipos: $\mathbf{E}=$ concavidade estrutural ajustada topograficamente a rede regional de canais (CEA); $\mathbf{S}=$ concavidade estrutural suspensa topograficamente em relação ao vale adjacente (CES); $\mathbf{A}=$ concavidade aberta ajustada topograficamente ao vale adjacente (CA); o zero indica sem canal; o um indica com canal (Lafayete et al. 1998).

A densidade de concavidades estruturais suspensas com canal (S1) e de concavidades abertas com canal (A1) é muito baixa e, portanto pouco expressiva na evolução de cabeceiras de drenagem. Frente ao exposto pode-se reavaliar que o percentual mais elevado de concavidades (29\%) obtido por Oliveira e Meis (1985), em diferentes localidades no médio vale do rio Paraíba do Sul, pode estar relacionado à posição destas localidades nas respectivas bacias, prevalecendo, talvez, o levantamento em locais situados no baixo e/ou no médio-baixo vale, onde as concavidades estruturais tornam-se, de fato, mais freqüentes do que nas áreas de montante.

\section{Formação de Canais e Origem das Concavidades Estruturais}

A dominância de concavidades estruturais, assim como o forte paralelismo entre a orientação dos seus eixos e das fraturas subverticais locais e a concentração de canais incisos (tipo voçorocas) no eixo das concavidades do tipo CEA e CES, levaram a investigar a sua origem enfatizando-se as suspensas, dados os espessos pacotes sedimentares que guardam uma complexidade inerente às sucessivas fases de retrabalhamento e reafeiçoamento.

\section{1- Estruturas Geológicas, Água Subterrânea e Mecanismos de Erosão}

Inicialmente, buscou-se compreender as relações entre fraturas subverticais e os fluxos d'água subterrâneos para avaliar as implicações na erosão responsável pela formação de canais descontínuos, observados particularmente entre a porção da encosta, imediatamente abaixo dos eixos de concavidades estruturais suspensas, denominadas degrau de encosta, e os fundos de vales adjacentes. Selecionouse uma concavidade característica, tributária de uma outra concavidade estrutural ajustada ao rio Bananal, situada na localidade Bom Jardim, onde ocorre o granitóide Rio Turvo, uma litologia mais homogênea, permitindo considerar, a priori, que o fraturamento subvertical representaria a principal descontinuidade do substrato rochoso (Figura 6-b). A topografia foi reconstituída em escala 1: 250 e o monitoramento hidrológico incluiu um pluviógrafo, baterias de piezômetros em diferentes profundidades e respectivos materiais (colúvios, interface colúviosaprolito e saprolito); também foram feitas mensurações volumétricas da erosão no túnel situado na cabeça de canais descontínuos, ao longo do degrau da encosta, como ilustra a Figura 8.

Avelar \& Coelho Netto (1992a e 1992b) apontaram os seguintes resultados: (a) a ocorrência de água subterrânea somente nos piezômetros instalados ao longo dos eixos principais e no saprolito, associado às fraturas subverticais locais; (b) as variações temporais das cargas de pressão não se relacionaram com as chuvas locais, sugerindo, desta forma, que a água seria proveniente do movimento ascendente do aqüífero regional (fluxo artesiano); (c) neste sentido, as chuvas precipitadas no âmbito da bacia do rio Bananal e adjacências seriam responsáveis por esse fenômeno.

O mapa de equipotenciais de carga total (Figura 9) indicou a convergência os fluxos d'água subterrâneos para jusante, em direção à base inferior do eixo da concavidade, abaixo do qual formam-se os canais descontínuos no degrau da encosta. $\mathrm{Na}$ cabeça desses pequenos canais geralmente ocorrem túneis erosivos (ou "piping"), alguns dos quais mostram a face da fratura na parede interna; esses túneis erosivos evoluem regressivamente (Figura 10). Os avanços remontante e lateral da erosão em túnel foram mensurados entre agosto de 1990 e setembro de 1991, obtendo-se uma taxa erosiva ordem de 0,092 m/ano. O colapso deste teto foi observado no ano 2000 , confirmando a hipótese anterior de iniciação de canais incisos a partir do colapso dos túneis erosivos que se formam ao longo de fraturas subverticais, cujo mecanismo erosivo dominante no recuo desses túneis está relacionado à exfiltração dos fluxos d'água artesianos, ao longo das fraturas subverticais, sob condição de descarga crítica, capaz de propiciar um excesso de poro-pressão na face de exfiltração.

\footnotetext{
2 O elevado gradiente topográfico da bacia do rio Bananal, parece explicar a geração de fluxos artesianos através dos sistemas de fraturas subverticais (Coelho Netto, 2002), como vem sendo observado e monitorado em outras localidades da bacia do rio Bananal (Rocha-Leão et al., 2002; Fonseca et al, 2002).
} 

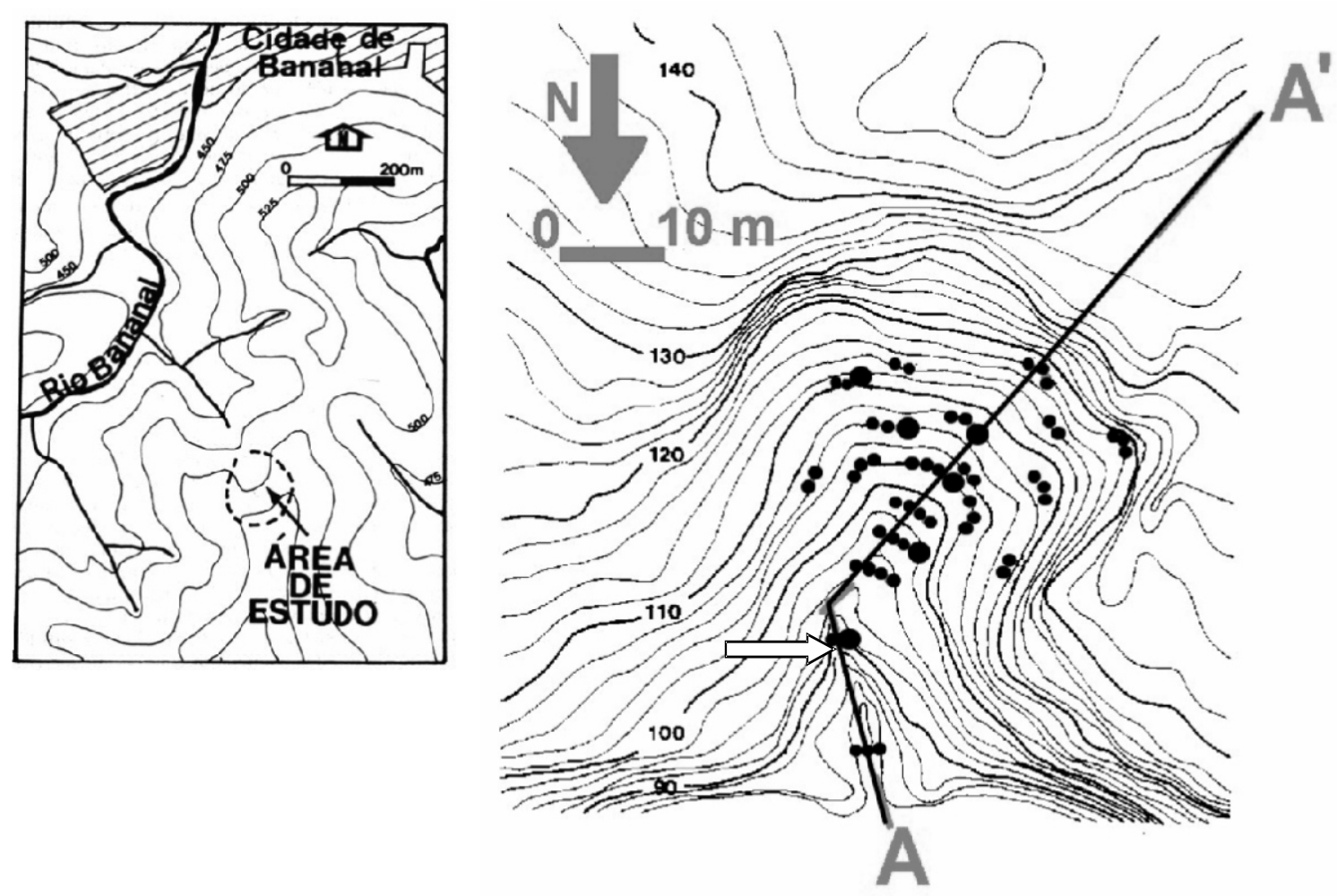

Figura 8 - Acima: localização da CES-Bom Jardim; abaixo: topografia da CES-Bom Jardim (1:250) e localização da rede de piezômetros e poços (pontos cinza): o círculo preto envolve os piezômetros no saprolito, únicos com água no período amostral e alinhados com as fraturas (linha tracejada); a seta branca indica a posição do túnel erosivo no degrau, abaixo do circulo preto inferior (mod. de Avelar e Coelho Netto, 1992b).
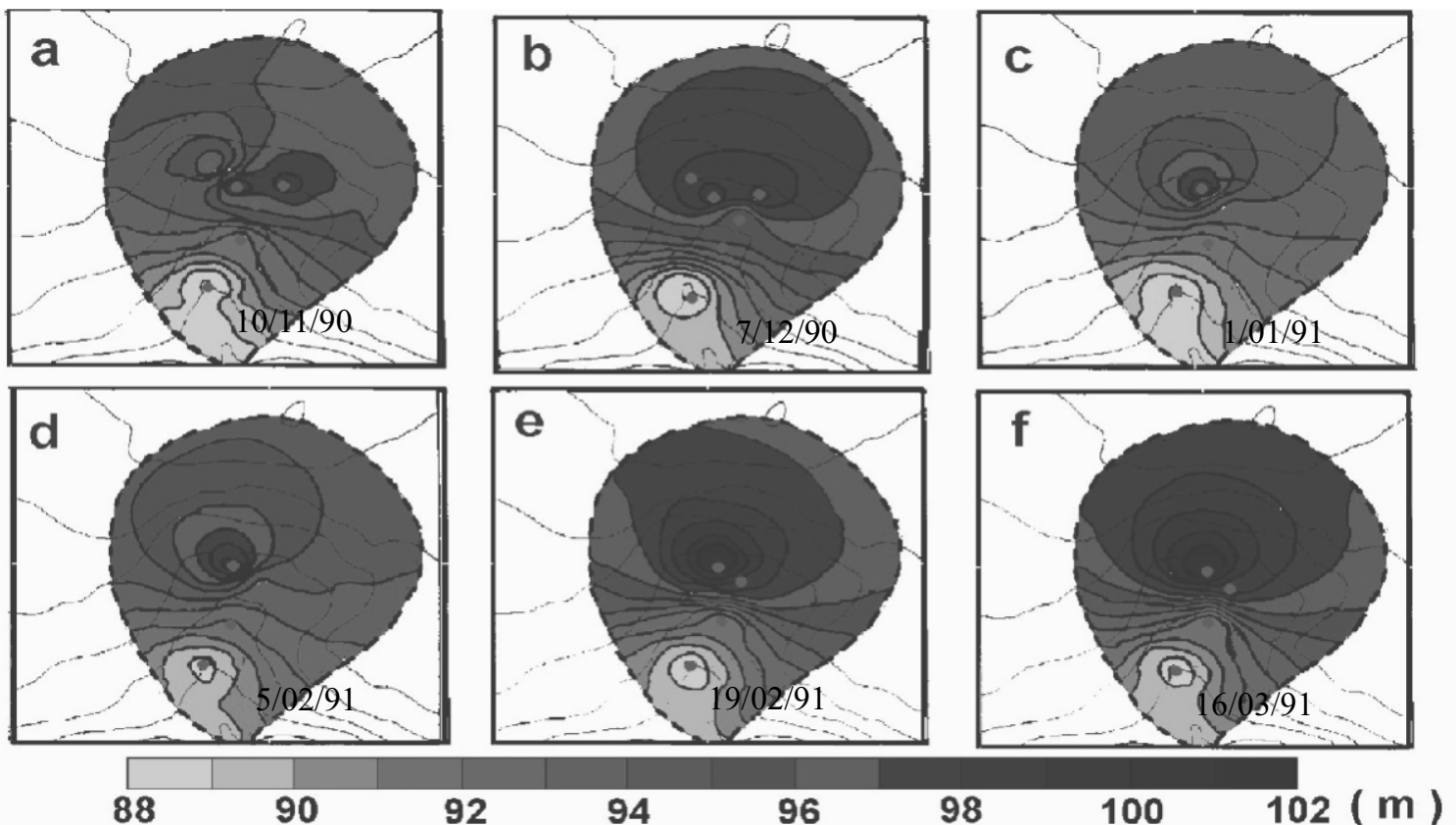

Figura 9 - Variação temporal das equipotenciais de carga total na CES-Bom Jardim, relativa ao nível altimétrico do rio Bananal. (mod. de Avelar e Coelho Netto, 1992b). 


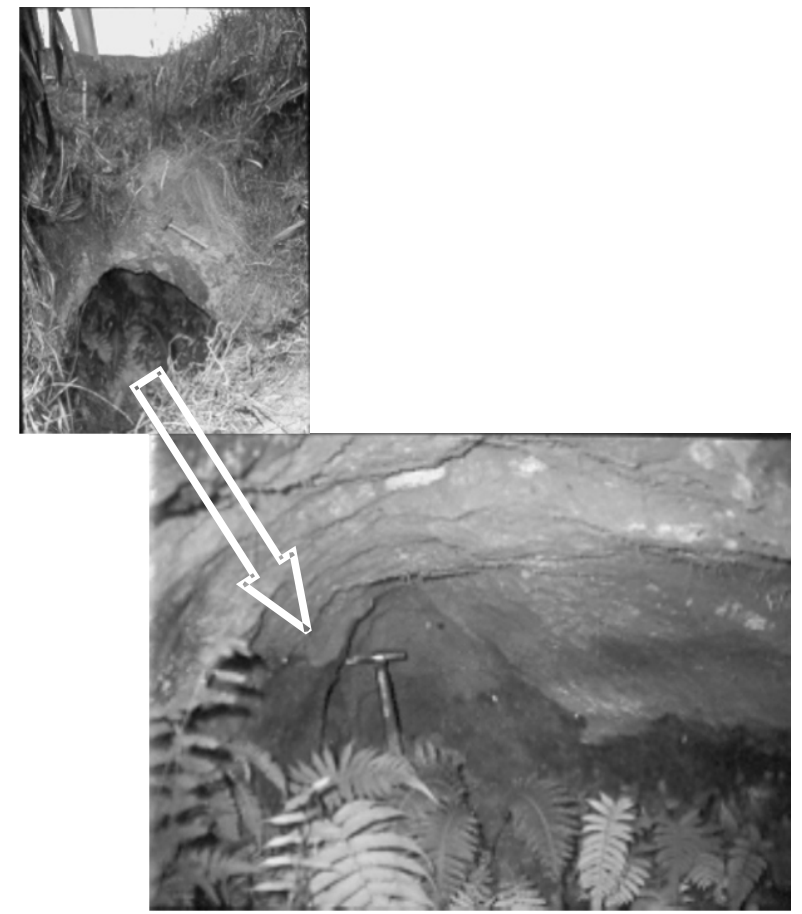

Figura 10 - acima: túnel erosivo em cabeça de canal descontínuo, no degrau de encosta adjacente a CES Bom Jardim; abaixo: visão da fratura subvertical na parede do túnel.

\section{2- Formação de Canais e Origem das Concavidades Estruturais}

Com base nos resultados acima, Avelar e Coelho Netto (1992a) propuseram um modelo para explicar a formação de canais, origem e evolução das concavidades estruturalmente controladas por fraturas subverticais e fluxos d'água artesianos (Figura 11).

A análise da associação entre fraturamento local e desenvolvimento de canais erosivos, sob diferentes litologias e tipos de concavidades, mostrou que para os casos amostrados no compartimento de colinas $(84 \%, \mathrm{~N}=38)$, prevalecia o padrão espacial anterior, ou seja, a densidade foi menor na área de granitóide Bom Jardim, menos fraturado e superior na área Três Barras, mais fraturada; nos outros locais mostraram valores intermediários.

Os resultados confirmaram a associação prevista, como mostra a Tabela 1.

Independente do tipo específico, em 10,4\% das concavidades estruturais observou-se a presença de fraturas na parede interna do túnel erosivo nas cabeças de canais; em $31,2 \%$ dos casos as fraturas subverticais mostraram-se visíveis no fundo do canal erosivo e, em todos os casos observados (100\%) verificou-se o paralelismo entre a orientação do eixo das concavidades estruturais e a orientação das fraturas subverticais locais.

A partir dessa constatação foram mensurados os parâmetros topográficos indicados por Montgomery \& Dietrich (1988) e Dietrich \& Dunne (1993) como relevantes limiares internos para a iniciação de canais, ou seja, tamanho da área de contribuição e gradiente, numa função inversa.

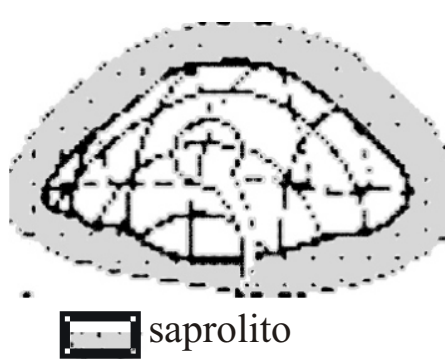

(a)

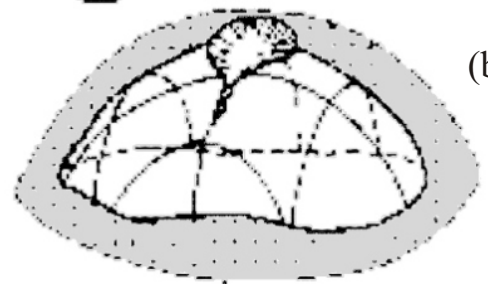

(b)

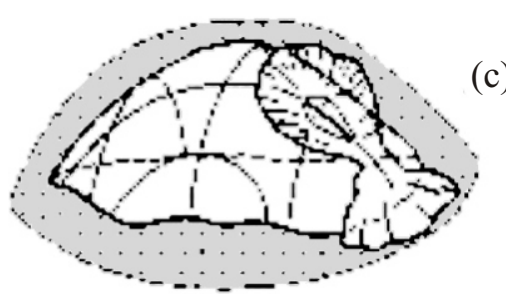

(c)

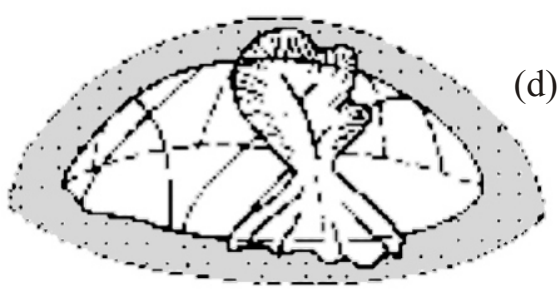

Figura 11 - Representação esquemática da formação de canais e concavidades controladas por fraturas subverticais e fluxos d'água artesianos (modificado de Avelar e Coelho Netto, 1992a): (a) formação de canais ao longo de fraturas ou a partir da interseção de fraturas; (b) incisão dos canais e abertura do vale por descalçamento da encosta adjacente, seguido por deslizamentos e erosão subseqüente; (c) recuo lateral e remontante das encostas por sucessivos deslizamentos e erosão subseqüente; d) expansão da rede de canais e respectivos vales tributários, controlados estruturalmente pela interseção de fraturas. 
Tabela 1: Posição de fraturamentos subverticais e freqüência de casos em concavidades estruturais ajustadas (CEA) e suspensas (CES), na bacia do rio Bananal (CEA/n=11; CES/n=37).

\begin{tabular}{|l|l|l|l|}
\hline LOCAL & $\begin{array}{l}\text { No } \\
\text { túnel } \\
\text { erosivo }\end{array}$ & $\begin{array}{l}\text { No } \\
\text { fundo } \\
\text { do canal }\end{array}$ & $\begin{array}{l}\text { No eixo } \\
\text { paralelo } \\
\text { ao canal }\end{array}$ \\
\hline CEA & 03 & 07 & 11 \\
CES & 02 & 08 & 37 \\
TOTAL (\%) & 10,4 & 31,2 & 100 \\
\hline
\end{tabular}

A Figura 12 evidencia que este modelo não se aplica diretamente nas cabeceiras do vale do rio Bananal, onde houve maior dispersão de valores, aliada ao fato de alguns canais iniciarem no próprio divisor de águas, o que desdobrou nossas questões, em relação ao que indicava a literatura: de um lado, a hidrologia subterrânea, responsável pela erosão associada à formação dos canais e das concavidades estruturais, não respondia diretamente às variáveis externas locais (chuvas, cobertura vegetal e infiltração local) e, do outro, não evidenciava relações diretas com limiares topográficos locais, ou seja, somente os
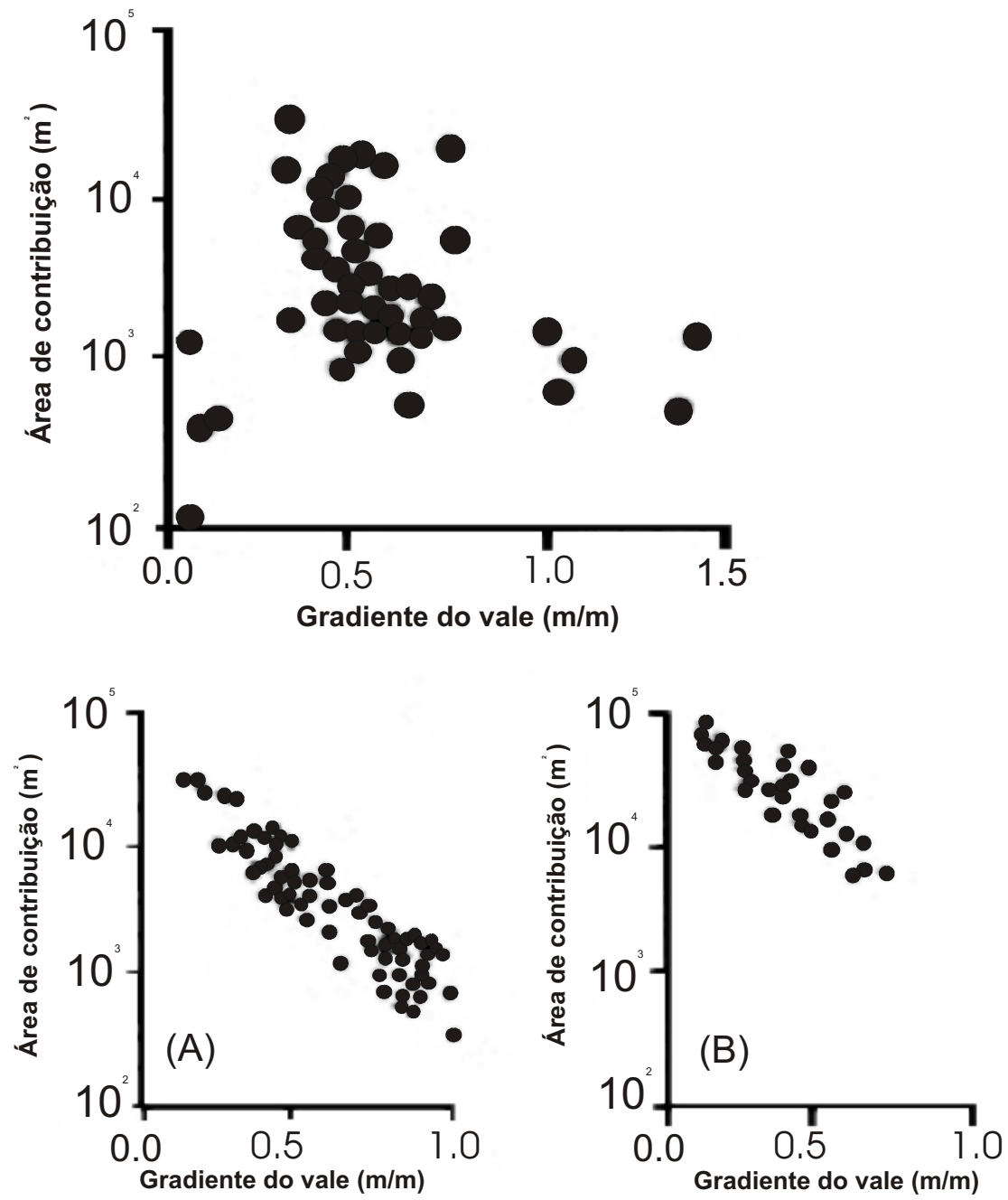

Figura 12 - Gráficos de correlação simples entre tamanhos da área de contribuição e o gradiente do vale de cabeceira: acima (Freitas et alli, 1995), na bacia do rio Bananal; abaixo (Montgomery \& Dietrich, 1988): A, no Oregon e B, na Califórnia. 
elementos físicos não explicariam a origem evolução destes vales, o que demandou conhecer e compreender melhor a influência dos processos químicos, particularmente no controle da formação e comportamento hidráulico e mecânico diferencial dos solos, assim como na esculturação das encostas.

\section{3 - Interações dos Processos Físicos e Químicos nas Concavidades Estruturais}

Felizola \& Boulet (1993 e 1996) ressaltam a importância da denudação química na formação de depressões fechadas, cuja evolução morfológica daria origem aos vales de cabeceiras de drenagem, com base em estudos efetuados no município de Caçapava (SP), sobre rochas sedimentares Terciárias e Quaternárias da bacia de Taubaté, marcadas por inúmeras falhas e fraturas (Formação Pindamonhangaba, descrita por Riccomini, 1989).

As depressões fechadas ocorrem no topo das colinas e apresentam um rebaixamento estreito na encosta lateral (ou passagem) com a base nivelada acima do fundo da depressão $( \pm 1,5 \mathrm{~m})$. Ao compararem as elevadas taxas de afundamento da depressão, da ordem de $0,23 \mathrm{~mm} /$ ano ou $23 \mathrm{~m} / 100.000$ anos, com a espessura da coluviação interna (em torno de $1,5 \mathrm{~m}$ ) os autores propuseram que a denudação química é mais eficiente do que a mecânica, na evolução dessas depressões.

Baseando-se na estreita relação entre o alinhamento das depressões e os lineamentos estruturais, esses autores indicaram, ainda, que o desenvolvimento das depressões foi favorecido pela perda vertical de água através dos sistemas de falhas, especialmente nas interseções dos falhamentos. Medidas piezométricas no interior das depressões estudadas evidenciaram que, após chuvas intensas, $o$ aqüífero temporário confinado na depressão fechada fluía internamente através da passagem estreita na encosta lateral, permitindo a exportação de solutos e o progressivo rebaixamento desta passagem até abrir a depressão. A partir desses estudos, os autores sugerem que a abundância de depressões fechadas e cabeceiras de vales com formas de anfiteatros, encontradas no vale do Paraíba, poderiam ser explicadas por lixiviação diferencial em área afetada por intensa atividade tectônica.

As depressões fechadas de topo são raras na bacia do rio Bananal, mas foi possível estudar uma delas na zona de cumeada da vertente esquerda da subbacia do alto rio da Fortaleza, inserida na Unidade São João: silimanita granada muscovita -biotita gnaisse, com intercalações de níveis ou lentes calciossilicáticas, gonditos, mármores e de silimanita muscovita - biotita-xisto, como descrevem Almeida et al (1989 e 1999). Na vertente direita, paralela ao mergulho das camadas geológicas, observou-se, no entanto, uma sucessão de concavidades estruturais suspensas típicas na base inferior das quais situam-se as cabeças de canais, incisas ao longo de fraturas subverticais e em rocha sã. Nessas concavidades o fundo está permanentemente saturado, assim como a vazão dos canais é perene, mesmo após longo período de estiagem, quando os solos imediatamente adjacentes estão secos, o que reforça a idéia de que as fraturas funcionam como via de exfiltração de fluxos d'água ascendentes (Leite e Coelho Netto, 2004).

Chama a atenção o fato destas concavidades do tipo CES, justapostas ao longo do divisor, apresentarem as cotas altimétricas do estrangulamento do vale decrescendo gradualmente para jusante, as quais associam-se a uma mesma camada xistoquartzítica resistente ao intemperismo. $\mathrm{O}$ aumento progressivo do tamanho dessas concavidades revela uma certa competição local pela captação e exfiltração da água subterrânea que responde pelo desenvolvimento dessas formas. Neste contexto, o rebaixamento do fundo de vale principal e do nível freático teria sido responsável pela estabilização morfodinâmica das concavidades suspensas. Seguindo esta ótica, tanto as concavidades estruturais suspensas, como a depressão fechada da vertente esquerda, poderiam ser vistas como formas-relíquias dos diferentes estágios evolutivos de uma mesma unidade morfológica, ou seja, das cabeceiras de drenagem do tipo $\mathrm{CE}$, ou até mesmo, da própria bacia de drenagem, que também mostra um forte paralelismo com as estruturas geológicas subjacentes.

Incorporando esse modelo investigou-se sobre a natureza das depressões fechadas e suas implicações com a origem das concavidades estruturais: seriam estas depressões os protótipos iniciais das concavidades estruturais, ou seja, seriam protovales estruturais que estabilizaram antes da fase de abertura dos vales de cabeceiras de drenagem?

Para responder esta indagação foi investigada a relação entre lito-estruturas, água subterrânea e intemperismo diferencial, tendo em vista a melhor compreensão dos mecanismos responsáveis pela erosão diferencial dos solos, em várias escalas de análise: das depressões fechadas ao vale fluvial. Para tanto, buscou-se integrar estudos pedo-geomorfológicos e geofísicos locais, com estudos hidro-geoquímicos e mineralógicos em escalas de bacia, incorporando a sub-bacia do rio Fortaleza, onde procedeu-se também monitoramento piezométrico e coletas de amostras (Figura 13).

Castro e Coelho Netto (2002) realizaram levantamentos detalhados de topografia, dos solos em toposeqüência e geofísicos por eletro-resistividade. A Figura 14 inclui uma visão panorâmica do divisor que contem a depressão estudada e na Figura 15 vê-se a sua topografia detalhada. A depressão é assimétrica e a primeira toposeqüência levantada situa-se na vertente mais curta e sob gradiente relativamente maior. $\mathrm{O}$ perfil elétrico (eletrorresistividade) foi traçado de lado a lado e atravessando o meio da depressão, estendendo-se um pouco além de suas bordas. 


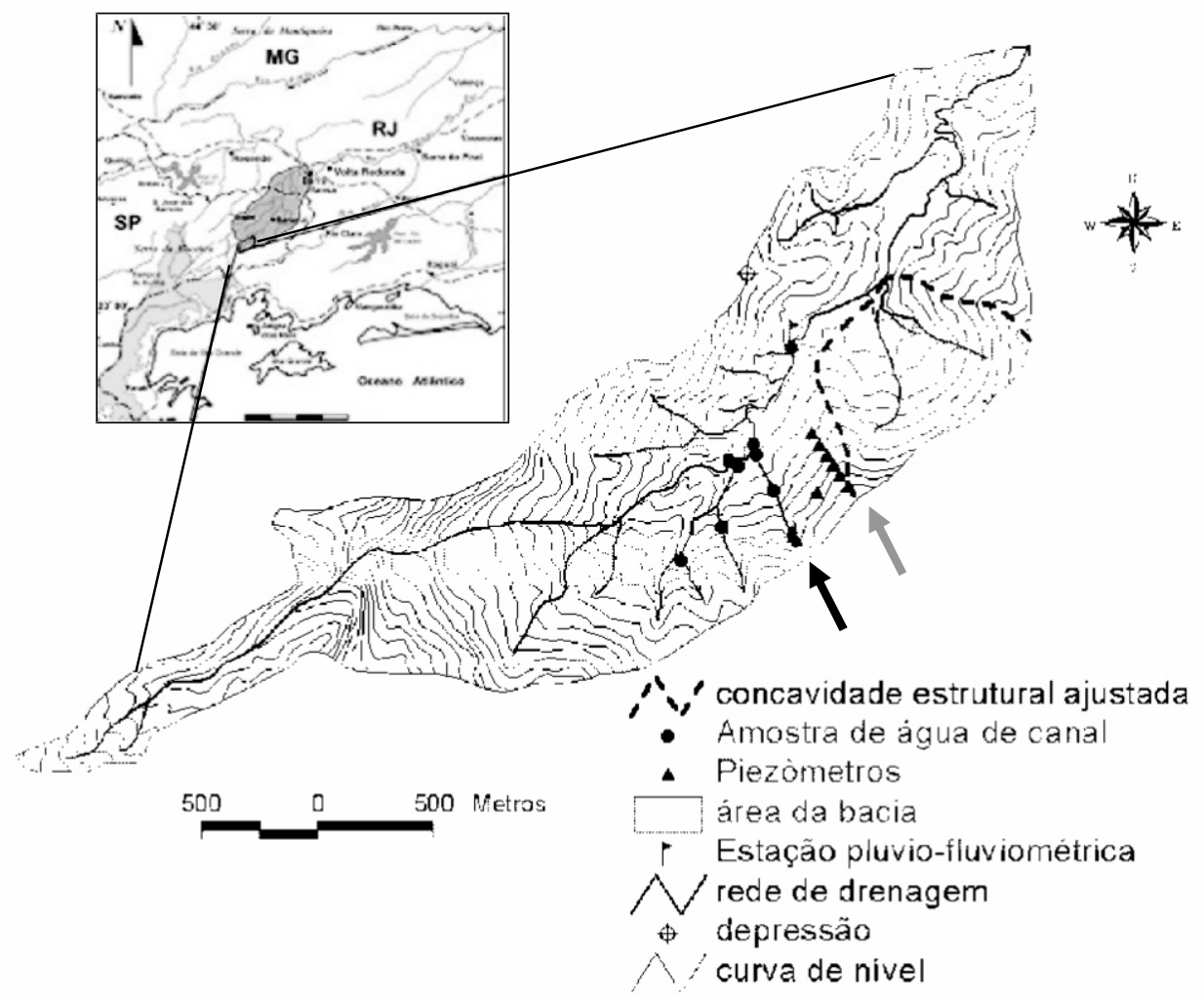

Figura 13 - Localização da sub-bacia do alto rio da Fortaleza $\left(4 \mathrm{~km}^{2}\right)$, que drena a Unidade São João; locais são indicados: a depressão fechada, os poços, piezômetros e coletas de solos: a seta preta indica a CES amostral e a seta cinza indica a encosta retilínea amostral; na saída da bacia localiza-se a estação pluviofluviométrica; em tracejado, uma concavidade estrutural ajustada ao canal principal.

Na toposeqüência, as autoras identificaram o sistema pedológico constituído de três tipos de solos: Latossolo Vermelho-Amarelo, na porção médiasuperior; Argissolo Vermelho-Amarelo Hidromórfico, na porção média-inferior e Gleissolo (hidromórfico) no centro da depressão, e o relacionamento à alteração do substrato gnáissico, pela presença de cascalhos quartzosos e litorrelíquias alteradas em todos os horizontes dos perfis de solo. A cobertura latossólica seria antecedente à formação da depressão e teria sofrido a transformação lateral para argissolo hidromórfico em associação com a formação da depressão. Os perfis de sondagem elétrica vertical, por sua vez, indicaram a ocorrência de uma zona de percolação subvertical em profundidade, localizada no centro da depressão, e correlacionada a fraturamento subvertical que atravessa um nível de aqüífero suspenso, em torno de $5 \mathrm{~m}$ a $8 \mathrm{~m}$ de profundidade, aparentemente alojado numa faixa de descontinuidade litológica, como mostra a Figura 16.

Com base nas evidências de campo, e perfil geoelétrico, as autoras supõem que a percolação no fraturamento subvertical teria favorecido a evolução da depressão por subsidência

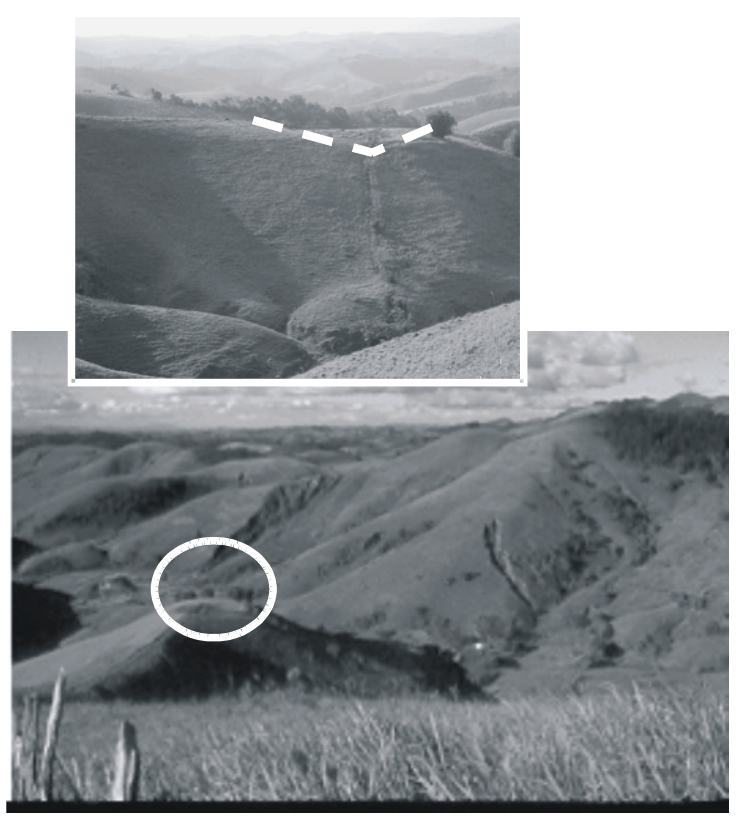

Figura 14 - no circulo branco: localização da depressão fechada na vertente esquerda da subbacia do rio Fortaleza; em tracejado: visão frontal de depressão com forma assimétrica. 


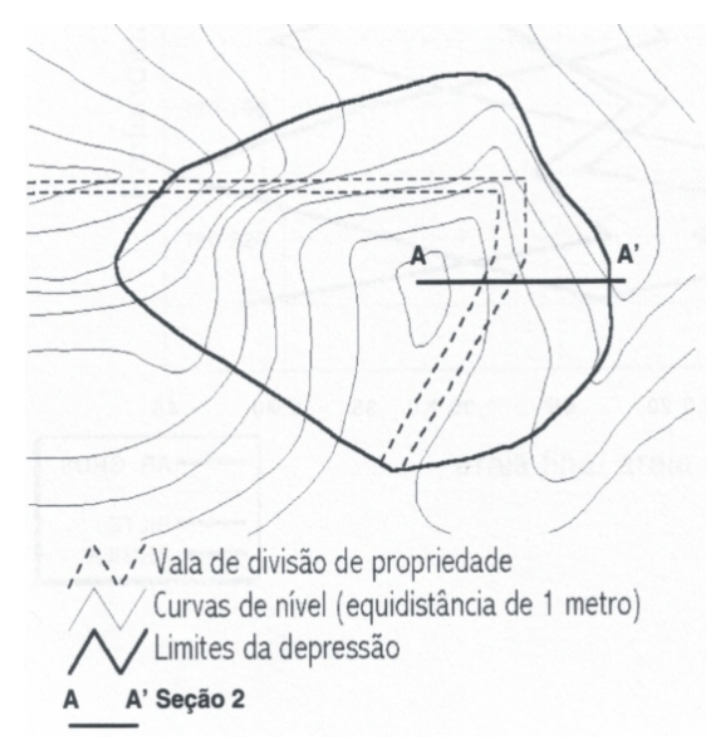

Figura 15 - Topografia detalhada da depressão fechada no divisor esquerdo da sub-bacia do rio Fortaleza; a linha dupla tracejada indica a vala artificial de $3 \mathrm{~m} /$ prof.Instruída no século 19 para drenagem e a linha A-A' a topossequência..

geoquímica, promovendo o rebaixamento do latossolo pré-existente e sua subsequente transformação por hidromorfia testemunhando a evolução para argissolo e gleissolos mais recente e correlativa da evolução da depressão.

Esta teria se desenvolvido em tempo relativamente lento, sem truncamentos erosivos, abatimentos ou colapsos relevantes, o que seria compatível com condições de subsidência geoquímica, mas não descartaram a possibilidade destes últimos fenômenos terem dado início à depressão, que passaria a acumular água. Vale ressaltar, no entanto, que, nesse sistema de fraturas subverticais os fluxos d'água ascendentes (ou artesianos) com os respectivos solutos, também não estariam descartados. Como nas depressões da Bacia de Taubaté, (Felizola \& Boulet 1996), a depressão da Fortaleza também é ligeiramente inclinada no sentido da vertente que drena para o rio Fortaleza, mostrando um certo rebaixamento na encosta mais baixa da depressão, como uma passagem suspensa, como é visto na Figura 15, o que a aproxima das concavidades estruturais suspensas que ocorrem ao longo do divisor na vertente direita, na mesma bacia, reforçando a hipótese de que elas se diferenciariam apenas quanto ao estágio de desenvolvimento. Ou seja, as depressões fechadas poderiam ser protovales, cuja evolução foi interrompida possivelmente por mudanças
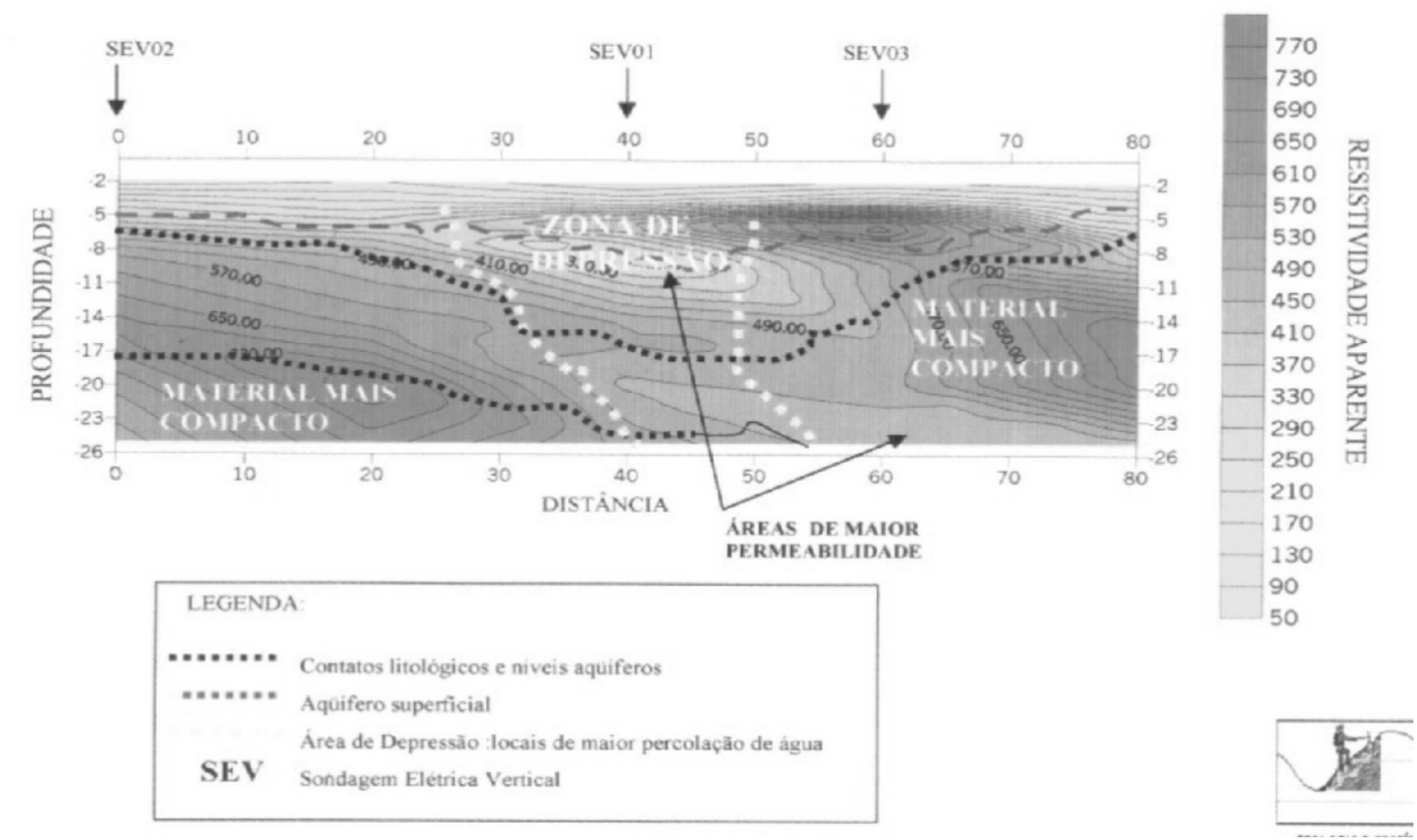

Figura 16 - Perfil de eletroatividade ao longo do divisor esquerdo da sub-bacia do alto rio da Fortaleza, passando no centro da depressão 
locais do regime hidrológico ou rebaixamento do nível freático regional, o que teria promovido sua estabilização, assim como das concavidades estruturais suspensas.

\section{mo diferencial \\ 4.4 Rotas de fluxos d'água e intemperis-}

Para avaliar a exportação de solutos através de fraturamento, Leite (Inédito) vem investigando as rotas de fluxos d'água subterrânea, monitorando a composição química das águas da chuva, do regolito/aqüífero e dos canais $\left(\mathrm{Ca}^{+}, \mathrm{Mg}^{2+}, \mathrm{Na}^{+}, \mathrm{K}^{+}\right.$, $\mathrm{SiO}_{2} \mathrm{HCO}_{3} \mathrm{Al}^{3+}, \mathrm{Fe}_{\text {total }}, \mathrm{pH}$ e Condutividade Elétrica), tendo em vista melhor compreender o intemperismo diferencial e suas implicações na evolução das cabeceiras de drenagem. Os pontos amostrais são os mesmos da Figura 13. No regolito, próximo ao divisor da vertente direita da sub-bacia do rio Fortaleza, verifica-se uma pequena variação dos elementos químicos analisados, evidenciando uma condição de baixa mobilidade (Figura 17).

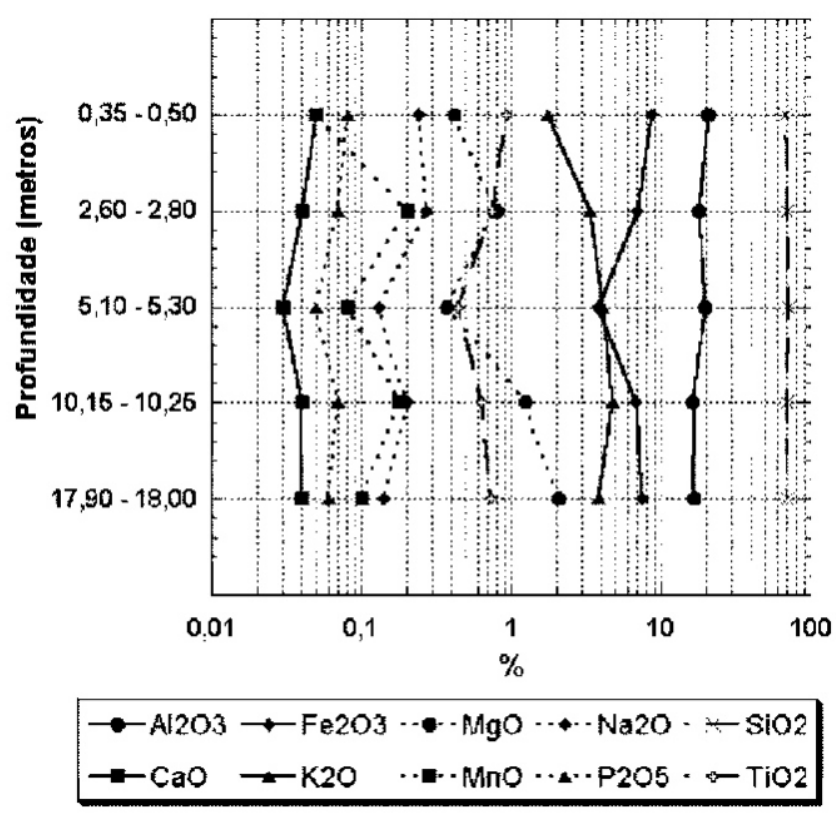

Figura 17 - Variação em profundidade dos elementos químicos do regolito no perfil 1, próximo ao divisor da encosta retilínea, na vertente direita da sub-bacia do rio Fortaleza, na bacia do rio Bananal (SP).

Numa primeira série temporal, num período de longa estiagem, observou-se um comportamento hidro-geoquímico uniforme ao longo dos canais fluviais perenes, indicando uma única fonte de água: o aqüífero subterrâneo regional.

Resultados mais recentes, incluindo a água do interior de uma concavidade estrutural suspensa e do canal inciso em fratura subvertical que acompanha o eixo desta mesma CES, na vertente direita, permitiram o reconhecimento de outras rotas de fluxos d'água.

A Figura 18 mostra a concentração média dos elementos analisados nos diferentes pontos, na segunda série de monitoramento iniciado em abril/2003 (Leite \& Coelho Netto, 2004). Observa-se, ao longo da rede principal de canais fluviais, que as concentrações dos elementos químicos permanecem baixas e com pequenas variações espaciais. Chamam a atenção, no entanto, as variações de concentrações dos elementos analisados nas águas do poço situado na CES (em torno de $8 \mathrm{~m}$ de profundidade), à montante da zona permanentemente saturada do fundo de vale, assim como no canal inciso na fratura associada a esta mesma CES, e no poço a jusante e próximo desse canal. As concentrações são mais elevadas do que nos fluxos d'água da rede principal, sendo que os maiores valores, em todos os elementos analisados, ocorrem no interior da CES; as concentrações decrescem no canal inciso na fratura, e novamente eleva-se no poço situado a jusante da CES. Este comportamento indica uma fonte de água local, suspensa em relação ao aqüífero regional, confirmando a evidência de lençol suspenso indicada no perfil elétrico. As diferenças de concentrações entre os locais refletem variações no tempo de residência da água, maiores no regolito, tanto no fundo da CES como nas adjacências imediatas.

No interior da CES, os maiores teores de 

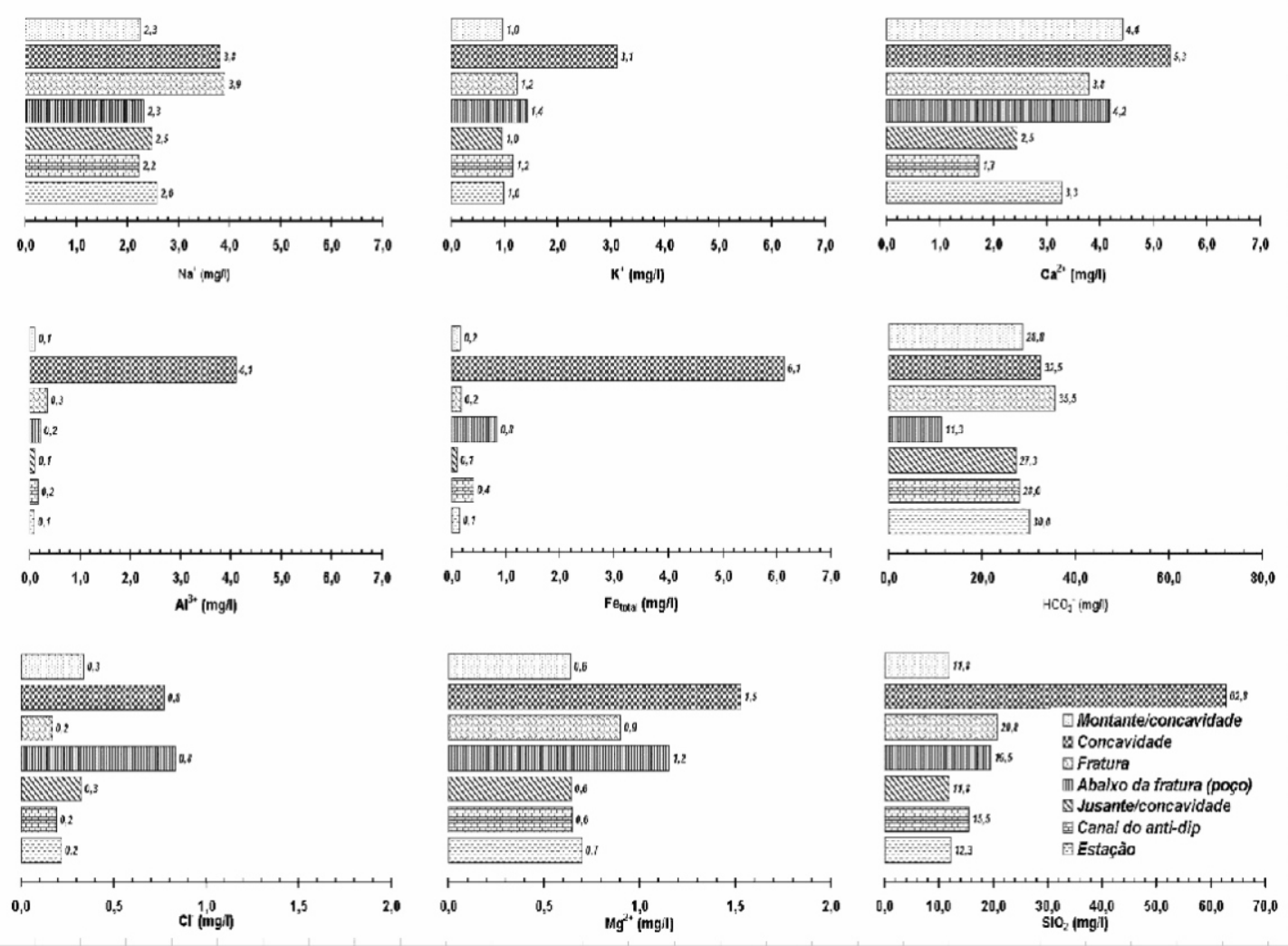

Figura 18 - Concentrações médias dos elementos químicos analisados nas águas da drenagem principal, no interior e entorno da concavidade estrutural suspensa e na vertente anti-dip (monitoramento de 2003/2004) - Leite \& Coelho Netto (2004).

ferro total e alumínio refletem as condições redutoras locais, as quais conferem características de hidromorfismo aos materiais do regolito (Xavier, 2004).

Nas águas coletadas no canal anti-dip que drena a vertente esquerda, onde ocorre a depressão fechada, as concentrações aproximam-se dos valores obtidos na rede principal de canais fluviais, variando, porém, nas concentrações de cálcio (mais baixas) e de sílica (mais elevadas, embora ainda inferiores à concentração de sílica na CES da vertente oposta). Leite \& Coelho Netto (2004) consideram que isto parece refletir a influência dos níveis ou lentes de rochas cálcio-silicáticas e mármores subjacentes, aí presentes. Considerando-se ainda que os materiais do regolito no interior desta bacia estão em estágio avançado de intemperismo, é possível que o cálcio, mais solúvel do que a sílica, também já tenha sido lixiviado e esta, mais abundante no regolito, ainda apresente concentrações superiores aos demais elementos. Finalmente, as autoras admitem que as variações, embora insuficientes para alterar o equilíbrio hidrogeoquímico da drenagem principal, onde prevalece a fonte de água do aqüífero regional, corroboram a idéia do intemperismo diferencial, ou seja, mais avançado no entorno imediato das fraturas funcionais sob percolação de fluxos d'água artesianos.

Com efeito, Xavier (2004) vem estudando a variação espacial do intemperismo na vertente direita da sub-bacia do rio Fortaleza, aplicando indicadores físicos (textura) e mineralógicos (minerais leves), em perfis localizados no interior da concavidade (perfis $10,9,8$ e 7 , de jusante para montante) e mais afastados, ao longo da encosta retilínea adjacente (perfis 6, 5, 4, 3,2 e 1, de jusante para montante), mostrados na Figura 19, onde apresenta-se a variação em profundidade da razão quartzo/feldspato $(\mathrm{Q} / \mathrm{F} \%)$ nas frações granulométricas de $0,5 \mathrm{~mm}$ e $0,125 \mathrm{~mm}$, nos perfis um e nove, tal como indicam Xavier et al. (2002).

No divisor da encosta retilínea (P1) uma certa preservação de feldspatos associa-se à pouca variação da razão $\mathrm{Q} / \mathrm{F}$ em profundidade, exceto numa faixa rasa (entre 3 e $4 \mathrm{~m}$ de profundidade). Arazão Q/F diminui em uma ordem de grandeza nas frações mais finas, como é de se esperar frente à quebra dos feldspatos nos seus planos de clivagem. Já no interior da CES a razão Q/F aumenta em mais uma ordem de grandeza reproduzindo um estágio mais avançado de intemperismo, uma vez que as maiores perdas de feldspato estão nos solos superficiais, a partir de onde a razão $\mathrm{Q} / \mathrm{F}$ decresce com a profundidade. 

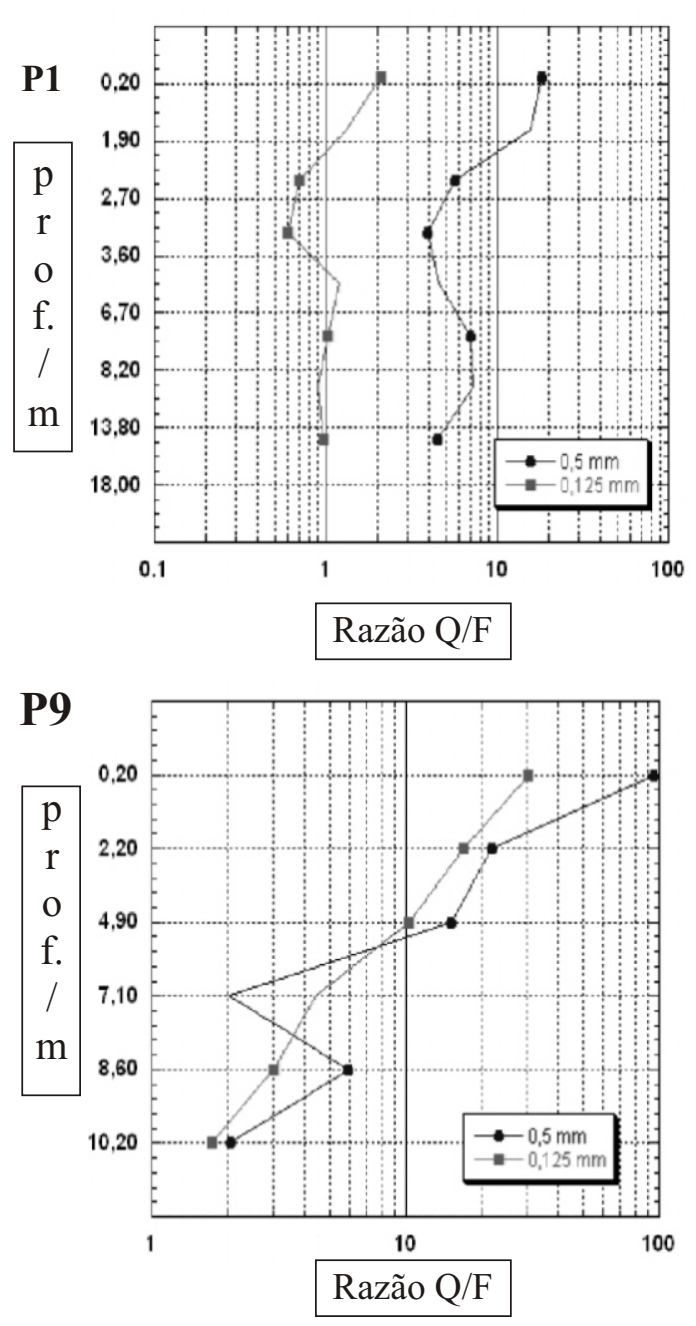

Figura 19 - Variação em profundidade da razão Q/P (\%) nos perfis 1 (próximo ao divisor/encosta retilínea) e 9 (próximo a zona saturada do fundo da CES amostral), ambos situados na vertente direita da subbacia do alto rio Fortaleza, na bacia do rio Bananal (SP).

$\mathrm{Na}$ Figura 20 percebe-se que esse comportamento acima se reproduz espacialmente, ou seja, na porção média-superior da encosta retilínea (P1, P2, P3 e P4) onde prevalecem baixos valores médios da razão $\mathrm{Q} / \mathrm{F}$. Cabe ressaltar, no entanto, que os valores mais elevados nos perfis cinco e seis da porção média da encosta, associam-se à presença de um aqüífero suspenso, observado durante as sondagens, o qual teria sido responsável pela maior eficiência do intemperismo local. Reproduzindo uma condição similar, de maiores perdas de feldspato em regolitos mais úmidos ou saturados, os perfis relativos ao fundo da concavidade estrutural suspensa (P7, P8, P9 e P10) também apresentam valores elevados da razão $Q / F$, o que configura uma condição de intemperismo mais avançada nas porções de encosta sujeitas à saturação, ou seja, por influência de aqüíferos suspensos ou no domínio de fraturas funcionais sob regime de fluxos artesianos.

Próximo ao divisor da encosta retilínea, o regolito apresenta uma pequena variação na proporção dos elementos químicos analisados, evidenciando uma condição de baixa mobilidade. Isto significa que, se por um lado o mecanismo de subsidência geoquímica parece haver favorecido a origem de depressões fechadas (ou protovales), por outro, a formação diferencial do regolito também pode ter favorecido a abertura, o alargamento e o aprofundamento dos vales de cabeceiras de drenagem ou concavidades estruturais.

Não há, portanto excludência entre os processos denudacionais de natureza química e física na origem das concavidades estruturais suspensas, sendo que o que provavelmente varia é a magnitude e freqüência destes processos nos diferentes estágios evolutivos dessas formas de relevo.

$\mathrm{Q} / \mathrm{F}(\%)$

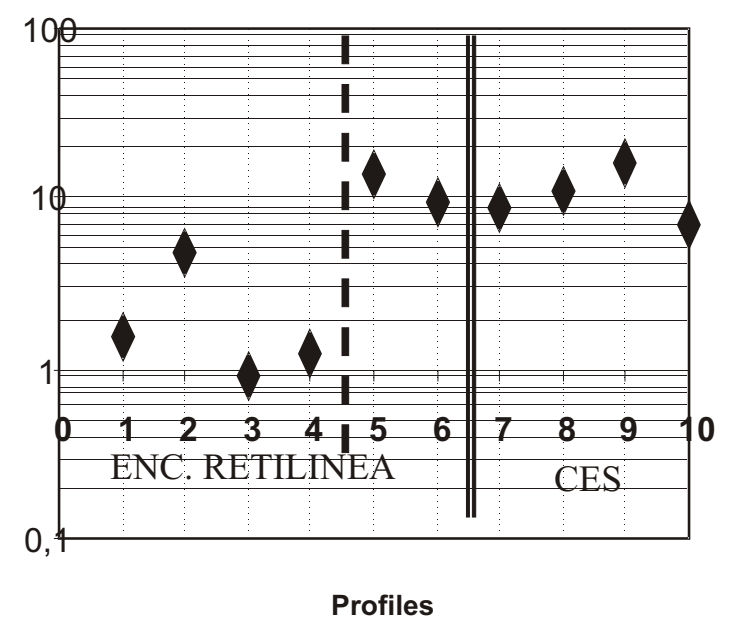

Figura 20 - Variação espacial da razão Q/F (\%) nos perfis de encosta retilínea ( P1-P6)e no interior de concavidade estrutural suspensa (CES/P7-P10), situadas na vertente direita da sub-bacia do alto rio Fortaleza, na bacia do rio Bananal (SP).

Levando-se em conta a lei gilbertiana de ajuste de declives (Gilbert, 1877), pressupõe-se que, na escala de tempo geológico, alguns destes vales suspensos, principalmente os mais efetivos na captura da água subterrânea, alcancem estágios mais avançados de desenvolvimento. Assim, espera-se que os vales de maior atividade erosiva possam se ampliar e bifurcar em vales tributários, igualmente associados à intercessão com outras fraturas funcionais, ou ainda, que possam romper divisores e incorporar os vales de cabeceiras adjacentes, como indicam as evidências morfológicas de campo e como já foi proposto por Meis e colaboradores com base nos estudos morfo- 
estratigráficos, como é discutido a seguir.

\section{Expansão da rede de canais sob controle estrutural}

A origem e desenvolvimento dos canais e vales de cabeceiras suspensos parecem espelhar um estágio evolutivo antecedente aos atuais vales de cabeceiras nivelados topograficamente com os canais fluviais principais. O crescimento remontante desses canais incisos através do eixo das concavidades estruturais decorre, primariamente, da ação dos fluxos d'água subterrâneos, configurando-se como canais incisos do tipo voçoroca. Para dimensionar e compreender os processos de voçorocamento foi selecionada a sub-bacia do rio Piracema (área em torno de $120 \mathrm{~km}^{2}$ ), principal tributário da margem esquerda do rio Bananal e adjacente a bacia do rio Barreiro de Baixo.

Cambra (1998) destaca que nessa sub-bacia ocorrem 117 voçorocas, dentre as quais cerca de $83 \%$ $(\mathrm{n}=97)$ correspondem aos canais de bifurcação externa da rede regional (ou canais de primeira ordem, segundo Strahler, 1952), e estão topograficamente ajustados ao nível de base dos canais fluviais adjacentes. Dentre elas, $53 \%$ são voçorocas estáveis, pelo menos temporariamente, e apenas $31 \%$ estão em atividade regressiva. Os casos restantes (17\%) correspondem às voçorocas que se desenvolveram em nível altimétrico suspenso, ou seja, independente da rede interconectada de canais (escala regional).

As voçorocas terminais da rede interconectada de canais estão incisas nos espessos pacotes de sedimentos de encosta (alúvio-colúvios e colúvios) que interdigitam com os pacotes de sedimentação fluvial, ambos co-relativos ao ciclo de agradação da transição Pleistoceno-Holoceno (entre 10.000 e 8.000 anos atrás). Estas voçorocas crescem regressivamente nos fundos de vales das cabeceiras do tipo CEA; em alguns anfiteatros maiores (complexos de rampas), o canal-tronco bifurcou ou está bifurcando em pequenos canais-dígitos, os quais também tendem a crescer regressivamente em direção ao eixo das subconcavidades estruturais do tipo CEA ou CES. O estágio de desenvolvimento é variável: as voçorocas estabilizadas, pelo menos temporariamente, apresentam vegetação arbustiva e arbórea no fundo do canal.

As voçorocas, assim como as concavidades estruturais que as contêm, ocorrem em diferentes litologias, porém, são mais freqüentes na vertente esquerda da sub-bacia, adjacentes ao vale do rio Barreiro de Baixo (66 casos ou 56,5\%), sendo 37,5\% estáveis e apenas $19 \%$ ativas. Na vertente direita, por sua vez, prevalecem as voçorocas ativas (21 casos ou $18 \%$ ) sobre as voçorocas estabilizadas (17 casos ou $14,5 \%$ ). Cabe ainda ressaltar que, dentre as voçorocas suspensas, 13 ocorrem na vertente direita e apenas $7 \mathrm{na}$ vertente esquerda (Tabela 2). Esta variação espacial parece refletir um aumento da vulnerabilidade erosiva próximo à zona de cisalhamento de Arapeí, onde as foliações e camadas rochosas estão mergulhando em ângulos maiores (até $\left.60^{\circ}-70\right)^{\circ}$, o que pode favorecer a recarga dos aqǘferos subterrâneos.

Tabela 2 - Número de voçorocas ajustadas à rede de canais e suspensas nas vertentes esquerda (V.E) e direita (V.D) da sub-bacia do rio Piracema.

\begin{tabular}{|l|l|l|l|l|}
\hline & Estável & Ativa & Suspensa & Total \\
\hline V. E. & 44 & 15 & 07 & 66 \\
V. D. & 17 & 21 & 13 & 51 \\
\hline
\end{tabular}

5.1- Mecanismos erosivos de voçorocamento

Estes estudos iniciaram-se em 1982 num vale de $1^{a}$ ordem, onde se desenvolve uma voçoroca típica, com um canal-tronco e alguns pequenos canaisdígitos, todos crescendo regressivamente ao longo dos eixos das concavidades, principal e tributária. Este vale situa-se no baixo vale do rio Piracema, na Fazenda Bela Vista, e por isto foi nomeado Anfiteatro Bela Vista (Figura 21). Trata-se de concavidade estrutural ajustada topograficamente ao fundo do vale fluvial adjacente, onde corre o rio Piracema, e que vem dissecando no saprolito da unidade geológica São João, constituída por biotita-gnaisse com bandamentos incipientes (descrita por Almeida et al., 1991 e 1993). Tanto o eixo principal, como os eixos das concavidades de ordem hierárquica inferior ocorrem paralelos à orientação de fraturas locais. Atualmente, a água subterrânea exfiltra o ano inteiro no fundo do canal-tronco da voçoroca, indicando como área-fonte o aqüífero regional, cujo afloramento já atinge os dígitos tributários.

Levantamentos estratigráficos e datação absoluta (40 amostras) nos depósitos de encosta do Anfiteatro Bela Vista e nos depósitos fluviais adjacentes, demonstraram que o ciclo de agradação da transição Pleistoceno-Holoceno foi sincronizado em ambos os vales (Dietrich et al., 1991; Coelho Netto et al., 1994). As observações de campo, nos primeiros anos de monitoramento da voçoroca Bela Vista, mostravam claramente a exfiltração na base do depósito Quaternário, constituído por bandas alternadas de diferentes cores e texturas (de areias grossas a argilosas). A exfiltração associada à erosão por excesso de poro-pressão só foi observada durante os períodos mais chuvosos, formando túneis erosivos pouco profundos, os quais rapidamente colapsavam, ocultando a face de exfiltração por um certo tempo, até 
que o material colapsado fosse removido no fundo do canal para, então, este mecanismo se repetir (Figura 22).

Coelho Netto et al. (1988 e 1990) descreveram os mecanismos atuantes no avanço regressivo da voçoroca, baseando-se nas observações de campo e em mensurações volumétricas da erosão nos primeiros anos de monitoramento, de 1982 a 1987.

A exfiltração do fluxo d'água subterrâneo que aciona o mecanismo erosivo primário, por excesso de poro-pressão é proveniente de duas fontes: uma associada ao aqüífero temporário ativado durante os períodos mais chuvosos de verão na base dos depósitos alúvio-coluviais, incoesos e altamente permeáveis, sobrepostos ao saprolito menos permeável; e outra, relacionada ao aqüífero regional que entra em operação de exfiltração após a remoção dos depósitos quaternários.

(1)

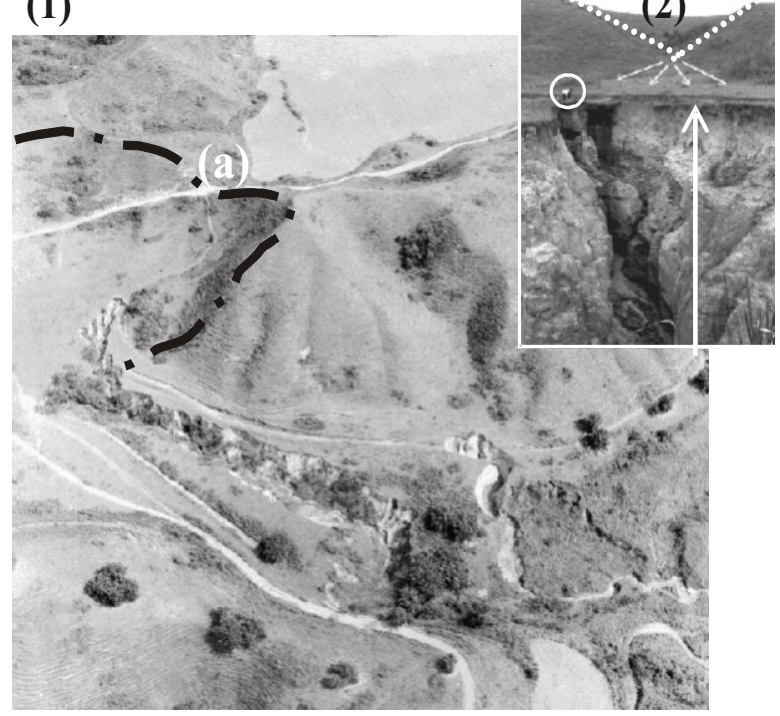

Figura 21 - (1) Vista panorâmica do canal-tronco e canais-dígitos (voçoroca) em avanço regressivo no anfiteatro Bela Vista: a linha preta contínua indica fluxo d'água permanente; a linha preta mais espessa é um segmento do canal do rio Piracema; (a) divisor recuado e rebaixado; no círculo, um pequeno canal-suspenso está se formando; na seta, uma $\mathrm{CE}$ originalmente suspensa, e que se ajustou topograficamente com a agradação do fundo de vale; (2) Visão frontal da CEajustada pela sedimentação vertical; no círculo, uma pessoa serve de escala.

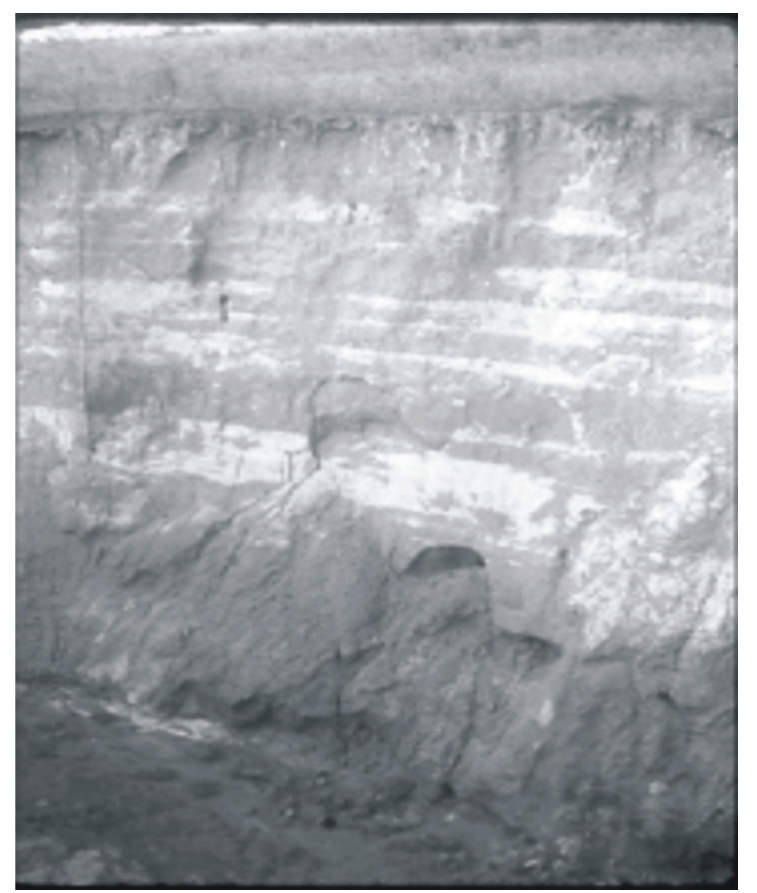

Figura 22: Túneis erosivos evidenciam a erosão por excesso de poro-pressão na face de exfiltração do aqüífero temporário, que se origina em períodos mais úmidos, na base do deposito Quaternário sobre o saprolito da Unidade São João, na borda lateral do canal-tronco da voçoroca Bela Vista.

No estágio erosivo anterior à incisão no saprolito obteve-se um taxa de erosão total da voçoroca da ordem de $3000 \mathrm{~m} / \mathrm{ano}$ (Coelho Netto et $a l, 1988)$. Analisando a morfometria das áreas-fontes que drenam para as cabeceiras de canais (tronco e dígitos), verificou-se que o recuo diferencial era controlado principalmente pela densidade de eixos de concavidades na área que converge para a cabeça dos canais, originando um parâmetro denominando de "densidade de concavidades" (Coelho Netto et al., 1988). Oliveira et al (1994), aplicaram este parâmetro ao conjunto de vales de cabeceiras dissecadas por voçorocas, no domínio de colinas do vale do rio Piracema, verificando que a extensão dos canais erosivos varia numa proporção direta com a densidade de concavidades, ou seja, quanto maior a densidade de concavidades, menor é a distância entre a cabeça do canal e o divisor de águas adjacente (Figura 23). 

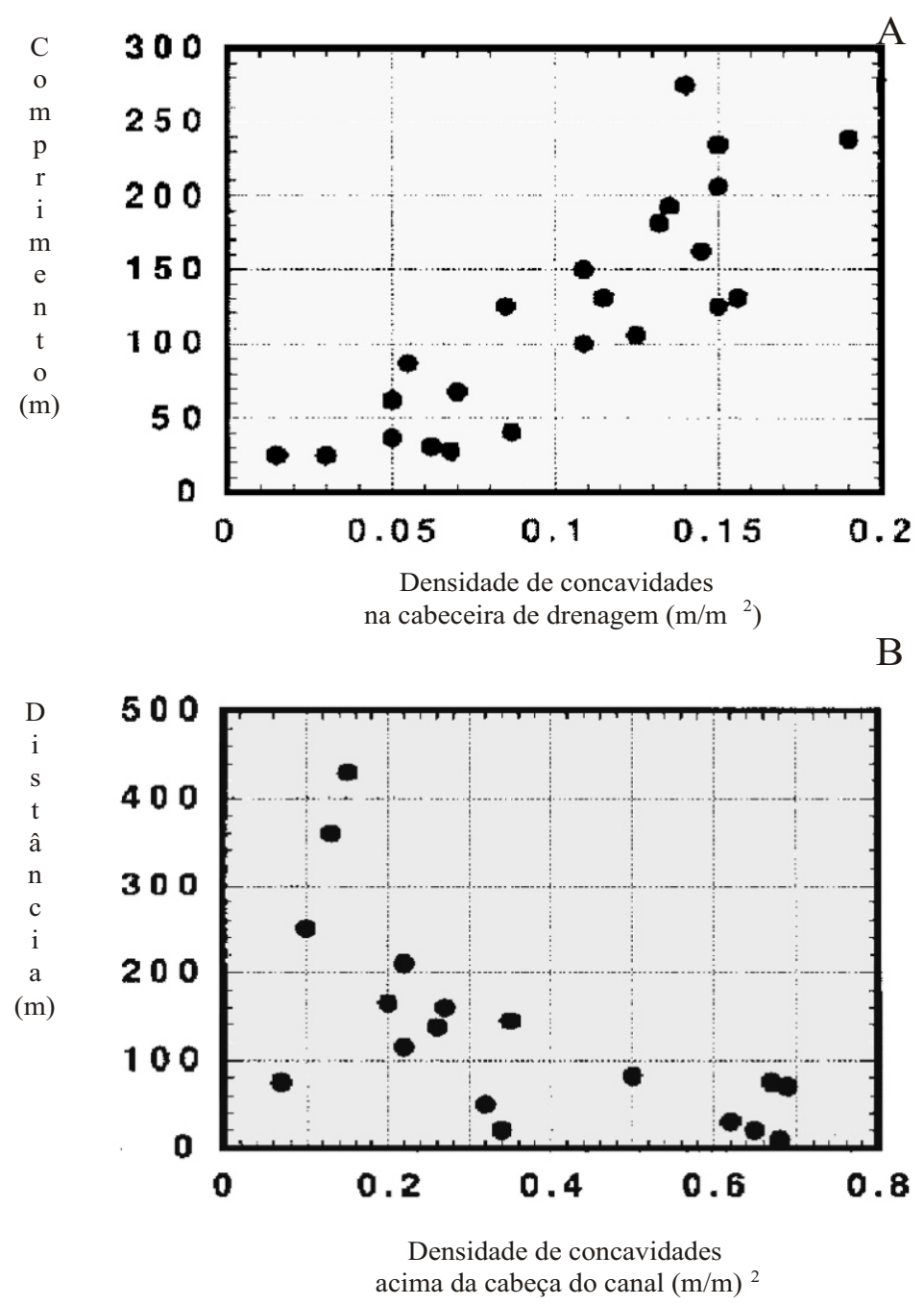

Figura 23: Gráficos de correlação simples: (A) entre densidade de concavidades de cabeceiras de drenagem comprimento dos canais de voçorocas; (B) entre densidade de concavidades na área de contribuição acima das cabeças de canais erosivos distância entre estas e o divisor (mod. de Oliveira et al, 1994).

Mesmo após a exumação do saprolito, a incisão linear permaneceu desacelerada na porção superior da voçoroca Bela Vista, por um certo tempo, em função da ocorrência de uma camada de colúvio mais resistente entre o depósito incoeso e o saprolito. Tal fato originou um degrau com cerca de um metro de altura (em 1982), mantendo em suspenso esta porção superior do canal e respectiva área de contribuição. $\mathrm{Na}$ seqüência das mensurações de erosão e, mais recentemente, com o monitoramento da hidrologia subterrânea, pode-se confirmar os mecanismos observados anteriormente; porém, novos fatos emergiram para explicar o crescimento da voçoroca (Rocha-Leão inédito).

5.2- Crescimento regressivo da rede de canais (ou voçorocas)
O aprofundamento do canal no saprolito, que resultou num certo rebaixamento do nível de base local, favoreceu o avanço regressivo do degrau interno da voçoroca e a aceleração da incisão linear na porção superior, na busca do ajuste de declive do canal erosivo como um todo. Aliado ao rebaixamento do nível de base e à progressão remontante no canaltronco, e no canal dígito que bifurcou à direita na interseção de fraturas subverticais, era de se esperar uma aceleração no avanço regressivo da voçoroca, tanto no tronco principal, como no canal-dígito. No entanto, até 1999, pelo menos, apenas o dígito bifurcante acelerou, enquanto a cabeça do canal tronco pouco evoluiu; nos últimos anos a voçoroca mantevese praticamente estável, como mostram a Tabela 3 e a Figura 24. 
Tabela 3 - Taxas de recuo (mªno) da cabeça do canal-tronco (D1) e do canal-dígito (D2), (in: Rocha-Leão et al., 2001).

\begin{tabular}{|c|c|c|c|c|}
\hline Posição & $\begin{array}{c}1982 \\
a \\
1984\end{array}$ & $\begin{array}{c}1984 \\
a \\
1987\end{array}$ & $\begin{array}{c}1987 \\
\text { a } \\
1994\end{array}$ & $\begin{array}{c}1994 \\
\text { a } \\
1999\end{array}$ \\
\hline D1 & 47,2 & 38,2 & 47,9 & 59,0 \\
\hline D2 & 15,9 & 32,0 & 21,8 & 15,85 \\
\hline
\end{tabular}
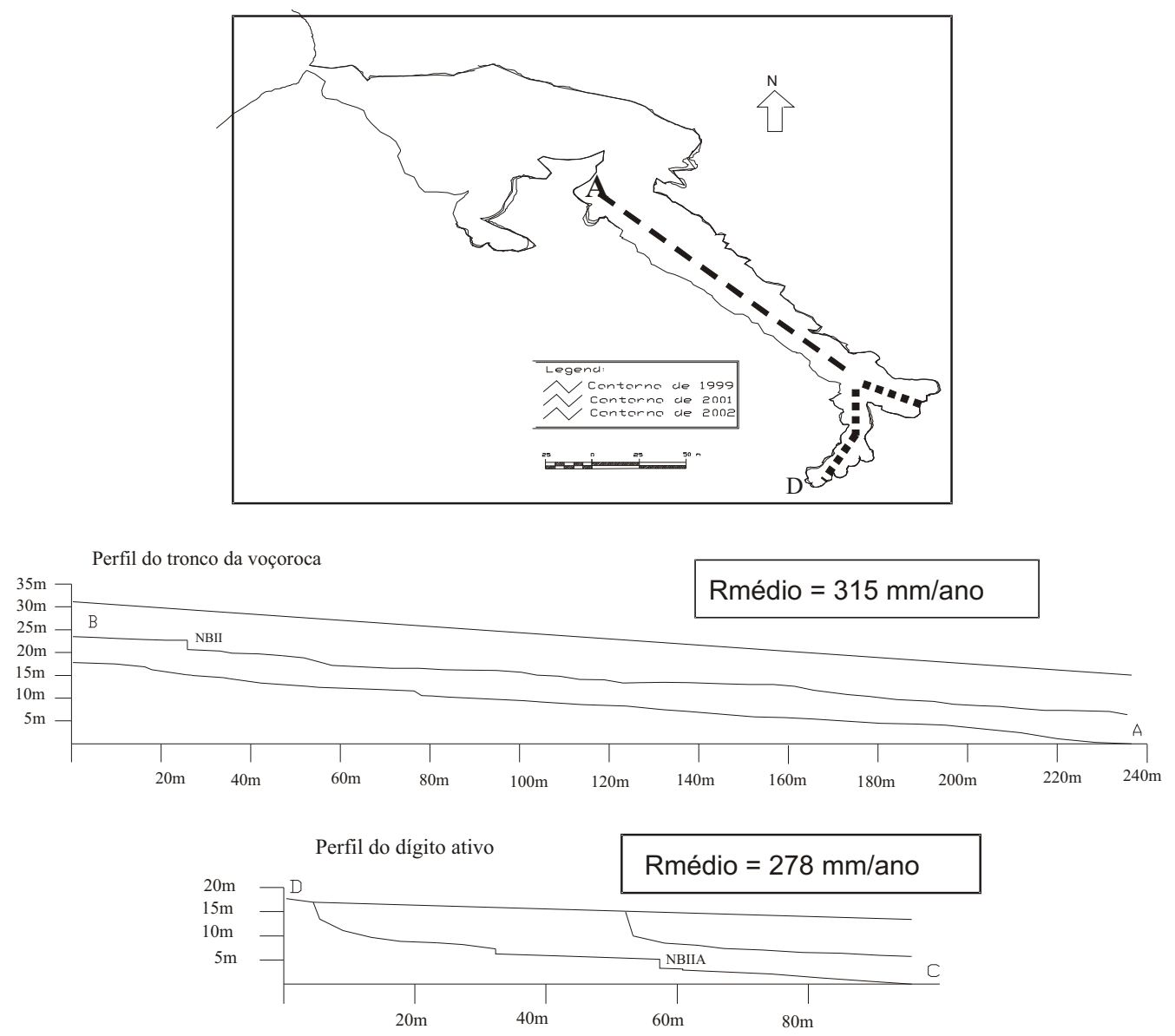

Figura 24 - Perfis topográficos da superfície erodida (linha superior), fundo do canal tronco (A) e do fundo do canaldígito mais ativo, em dois tempos: 1982 e 2001, no Anfiteatro Bela Vista. Rmédio = taxa de rebaixamento.

Se por um lado não se verificou uma relação direta entre o rebaixamento do nível de base interno da voçoroca e a regressão do canal erosivo, por outro, verificou-se uma associação com o rebaixamento do lençol freático, o que pode ter restringido a freqüência de descargas críticas nas faces de exfiltração, tanto no fundo como nas bordas do canal erosivo. A Figura 25 ilustra a flutuação do nível d'água subterrânea num dos piezômetros instalados a montante do canal-dígito da cabeceira em dois períodos e as respectivas distribuições de chuvas diárias registradas na Estação
Bananal.

Embora os dois períodos amostrais apresentem variações na pluviosidade entre si, parece evidente que no período mais recente o nível d'água médio rebaixou. De fato, os demais piezômetros e poços instalados no anfiteatro não têm apresentado água nos últimos anos, a não ser em caráter excepcional de chuvas no âmbito da bacia do rio Bananal.

Estudos mais recentes sobre o comportamento de carga total piezométrica em vales 

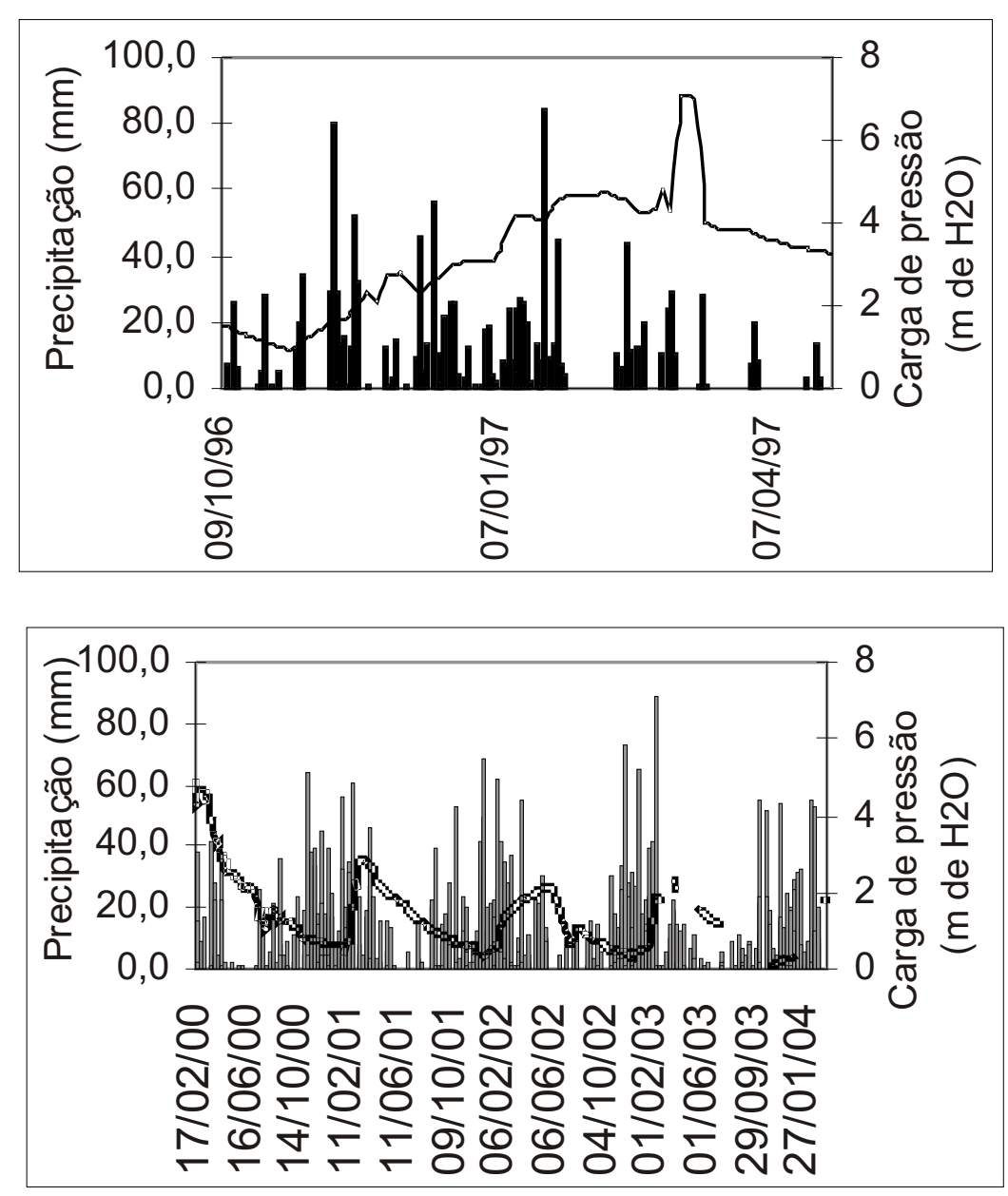

Figura 25 - Variações do nível d'água no poço situado a montante do canal-dígito da porção superior da voçoroca Bela Vista e das chuvas locais, em dois períodos distintos.

de cabeceiras adjacentes ao anfiteatro Bela Vista evidenciam o deslocamento dos divisores de água subterrânea em relação aos divisores topográficos (Leal, 2004). Este autor destaca a convergência de fluxos do vale adjacente, sobre a qual avança o divisor à montante do canal-dígito mais ativo nos últimos anos. Em contrapartida, a rede de fluxos também evidencia que o anfiteatro Bela Vista já perde água para o vale adjacente à montante da cabeceira do canal tronco (Figura 26), o que reforça o modelo de pirataria de água subterrânea entre vales adjacentes, na evolução diferencial dos vales de cabeceiras como sugerido anteriormente.

\section{Drenagem}

\section{3- Recuo dos divisores e Capturas de}

O avanço regressivo dos canais erosivos em direção à encostas traseiras de maior gradiente topográfico tende a promover sua instabilização, catalisando a ocorrência de movimentos de massa. Este processo, associado ao avanço regressivo dos canais erosivos em cabeceiras de drenagem, vem sendo investigado junto com Willy A. Lacerda (COPPE-UFRJ) e estudado num vale de cabeceira tributário do rio Bananal, sobre gnaisse bandado (Unidade Três Barras).

Neste local, o intemperismo diferencial é favorecido pela ocorrência de camadas geológicas com diferentes composições mineralógicas e texturais, aliado ao artesianismo com surgência, que está sendo mensurado à jusante da curvatura do eixo principal por Fonseca (inédito). $\mathrm{O}$ bandamento no saprolito alterna camadas com diferentes características físicas, químicas e mineralógicas marcadas pela ocorrência de níveis quartzofeldspáticos mais resistentes, e níveis biotíticos, que resultam em diferentes propriedades hidráulicas e mecânicas e favoreceram a constituição de superfícies potenciais de ruptura (Coelho Netto, 1997; 1999).

A Figura 27 mostra o deslizamento na concavidade Três Barras, do tipo CEA, enquanto a Figura 28 reconstitui a topografia detalhada. Nestas figuras percebe-se que o desvio do canal erosivo à 


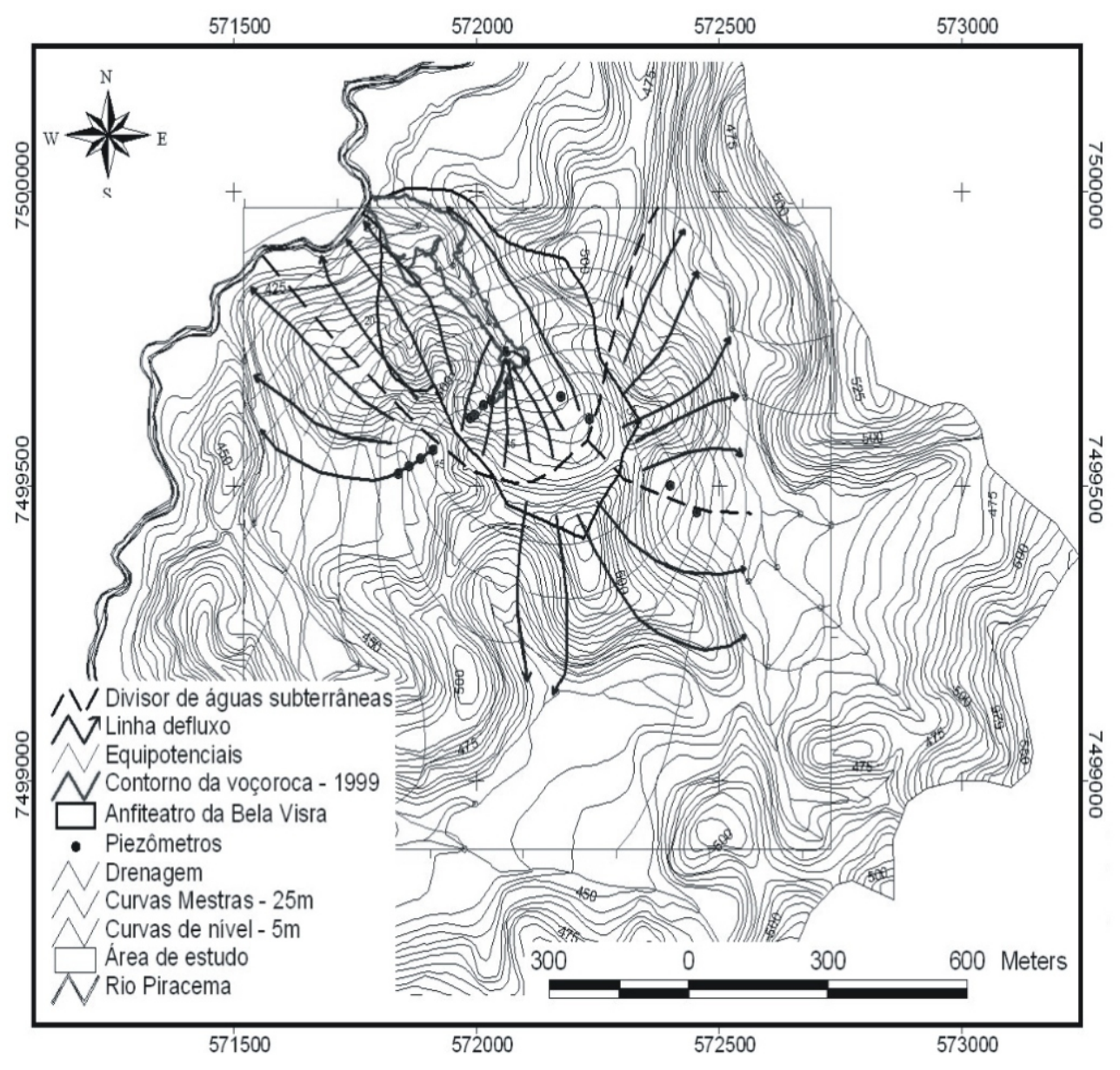

Figura 26 Rede de fluxos d'água subterrânea no Anfiteatro Bela Vista (ao centro) e cabeceiras de drenagem adjacentes: as setas indicam as direções dos fluxos d'água subterrâneos e a linha tracejada evidencia os divisores desses fluxos (sem correspondência com os divisores topográficos).

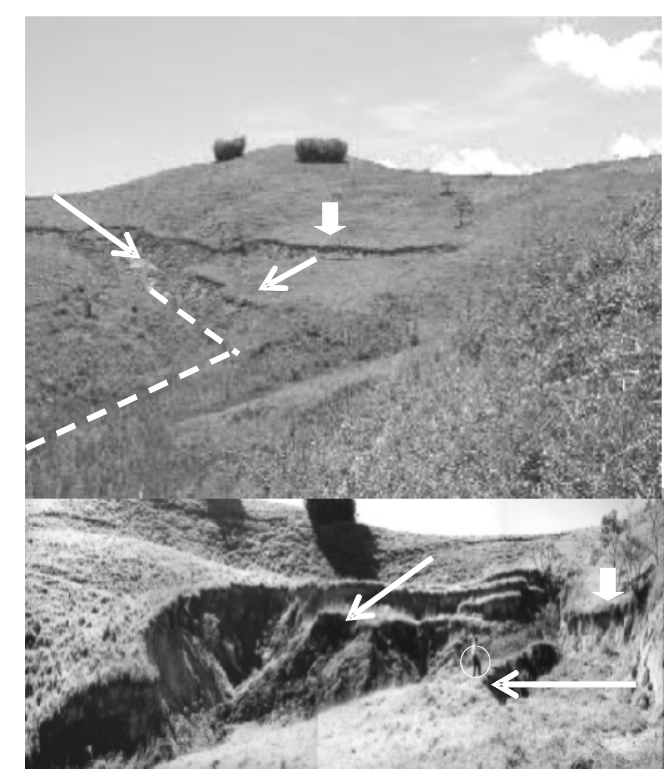

Figura 27. Avanço regressivo do canal-erosivo (voçoroca) na encosta traseira do anfiteatro Três Barras; o descalçamento da encosta pelo voçorocamento propiciou o deslizamento em dois sentidos, como indicam as setas brancas (acima e abaixo); as setas pretas localizam a fenda de tração associada ao movimento do regolito para jusante; o circulo indica uma pessoa para escala. 


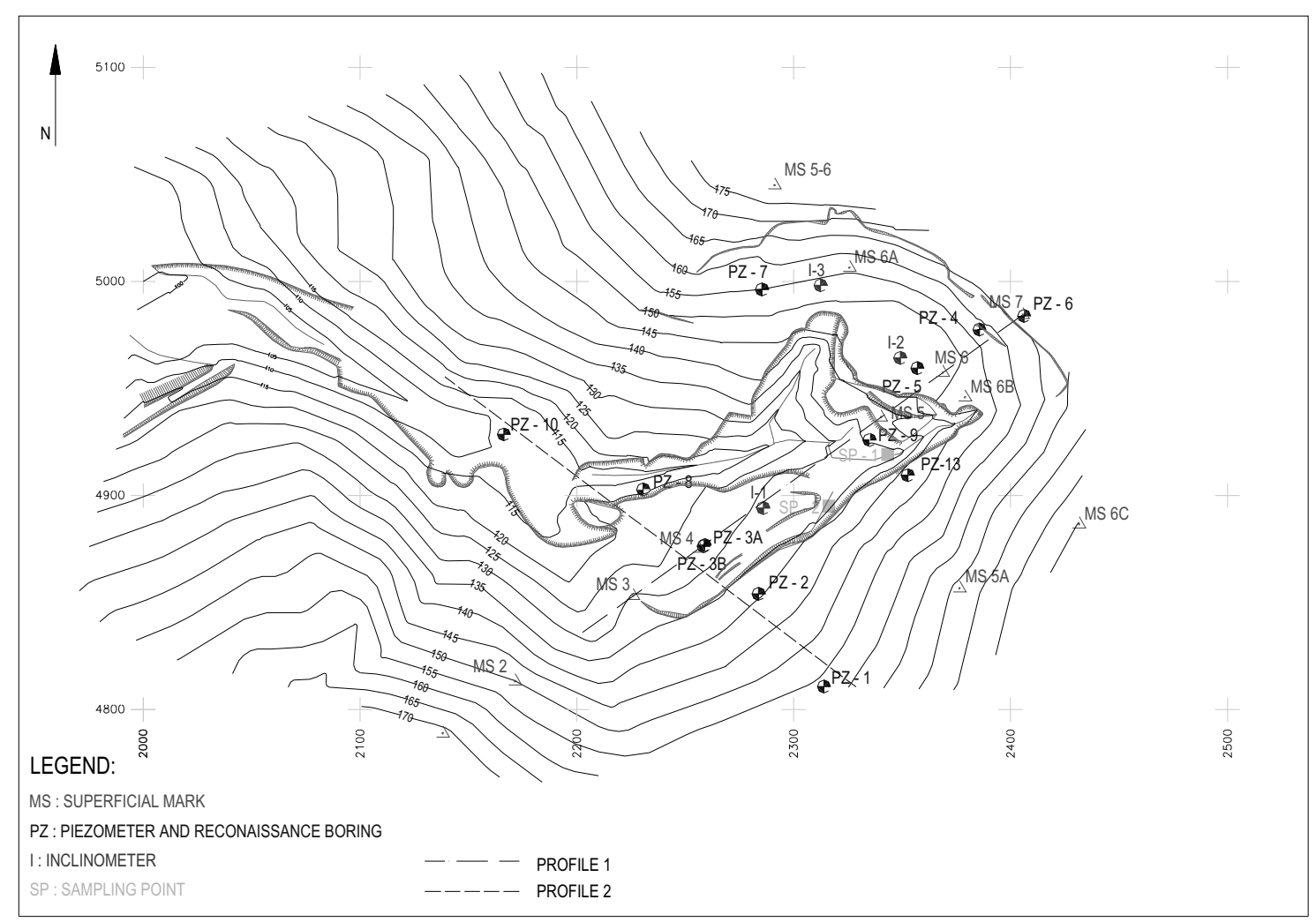

Figura 28 - Topografia detalhada do anfiteatro três Barras (Fonseca et al, 2002): notar o contorno do canal-tronco, e do deslizamento em duas direções; as linhas no alto da cabeceira indicam as trincas associadas ao deslizamento nos dois sentidos; as retas tracejadas marcam o eixo do vale.

esquerda promoveu um amplo descalçamento da encosta traseira, mais íngreme, favorecendo a movimentação dos materiais em dois sentidos.

Observações de campo revelam a superfície de ruptura sobre a qual esta massa está se deslocando lentamente, um nível quartzoso mais resistente e impermeável, sobre a qual ocorre uma outra banda rica em feldspato muito alterado. À medida que a massa se desloca para o fundo do vale provoca um efeito de deslocamento remontante como indica a fenda de tração na encosta traseira do canal-tronco e as trincas paralelas ao divisor à direita do vale, o que reproduz o processo primário de recuo do divisor, junto com outros mecanismos secundários de lavagem superficial na cicatriz exposta e nos materiais deslizados.

Evidências morfológicas de divisores recuados e rebaixados, invertendo parcialmente a funcionalidade da topografia local são comuns na paisagem da bacia do rio Bananal, tal como ocorreu a montante do canal-dígito superior da voçoroca Bela Vista. durante o ciclo erosivo-deposicional da transição Pleistoceno-Holoceno (Coelho Netto, 1999).
Em algumas localidades, o recuo do divisor de um vale de cabeceira pode coalescer com outro vale de cabeceira adjacente, rebaixando os respectivos fundos de vales até inverter totalmente o relevo, ou seja, até o antigo divisor passar a funcionar como fundo de vale, ou zona de convergência de fluxos d'água, como é visto na Figura 29. Meis \& Moura (1984) descreveram essas inversões de relevo em diversas localidades do médio vale do rio Paraíba do Sul, assim como no médio vale do rio Doce. As autoras observaram ainda que o avanço regressivo pode cruzar os divisores e induzir a captura de canais de drenagem entre vales adjacentes.

Segundo Coelho Netto \& Fernandes (1990), as capturas são favorecidas pelo desnivelamento topográfico entre fundos de vales adjacentes e paralelos entre si, o que favoreceria a pirataria de água subterrânea do vale suspenso, tal como demonstram os estudos recentes de Leal (2004). Esta condição é vista no vale do córrego Campo Alegre, afluente do rio Barreiro de Baixo, o qual está suspenso por um nível de base rochoso logo à montante da confluência com o rio principal. 


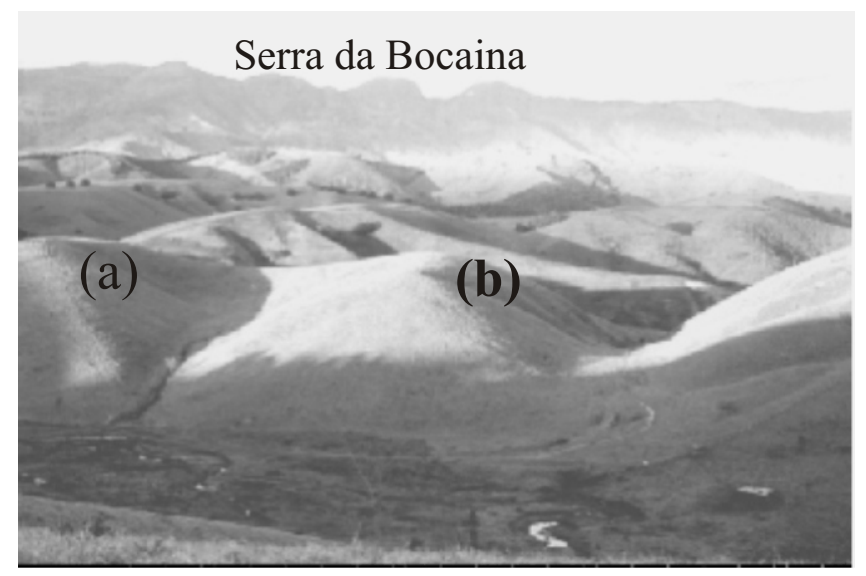

Figura 29 - Recuo de divisores: A - Recuo parcial; B - Recuo e coalescência de vales de cabeceiras adjacentes (inversão de relevo): o divisor é rebaixado e submetido à mudança funcional, ou seja, deixa de ser área de divergência de fluxos e passa a ser área de convergência de fluxos.

A Figura 30 ilustra a expansão regressiva de canais (voçorocas), assim como, o recuo do divisor e a inversão parcial do relevo, tal como ocorreu em diversos vales de cabeceiras de drenagem, assim como no anfiteatro Bela Vista e no vale tributário do rio Barreiro de Baixo; neste último a progressão remontante acarretou a captura de drenagem do vale do córrego Campo Alegre.

A montante desta captura intensificou-se a incisão linear no fundo de vale do canal capturado, em busca de um novo ajuste de declive com o nível de base do vale capturador, ou seja, do rio Barreiro de Baixo. Por outro lado, o segmento do vale fluvial à jusante da captura manteve-se estável. Este mecanismo de retroalimentação positiva da degradação dos canais, associado à pirataria de água subterrânea entre vales adjacentes, também foi recentemente descrito por Pederson (2001) na região de Alaka Falls, no Havaí.

Integrando os processos de erosão linear e avanço remontante dos canais erosivos sobre as cabeceiras de drenagem com os deslizamentos que promovem o recuo dos divisores, propõe-se que a evolução das cabeceiras de drenagem envolve três etapas principais. A primeira refere-se à remoção dos pacotes sedimentares acumulados nos ciclos de agradação, os quais até então propiciaram a ocultação das faces de exfiltração associadas aos fluxos artesianos. Nesta etapa, a densidade de concavidade

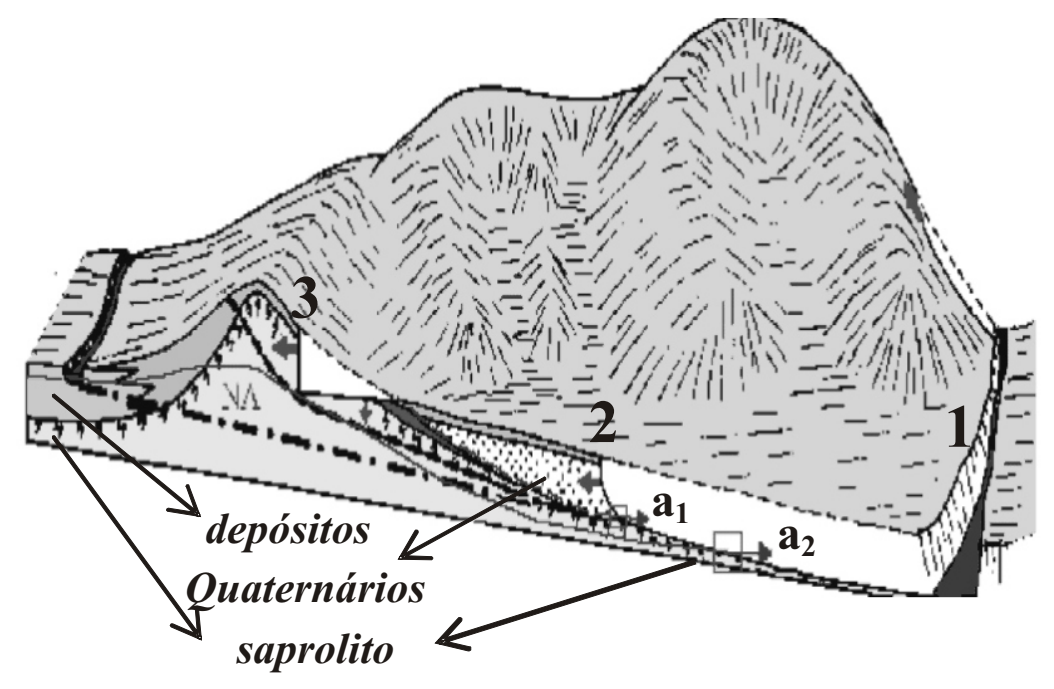

Figura 30: Representação esquemática da expansão regressiva da rede de canais ajustados e/ou suspensos em relação à rede regional (mod. de Coelho Netto et al., 1988): 1-canal principal, 2-cabeça do canal de bifurcação da rede principal, e 3- cabeça do canal descontínuo da rede principal; $\mathbf{a}_{1}=$ altura inicial do aqǘfero (exfiltração na base dos depósitos Quaternários); $\mathbf{a}_{2}=$ rebaixamento do aqüífero com a incisão progressiva do canal no saprolito (Rocha-Leão, inédito). $\mathrm{Na}$ encosta lateral do canal principal, representa-se a formação da concavidade aberta por solapamento da base da encosta. 
multiplicada pelo gradiente da área de contribuição exerce um controle sobre a eficiência dos fluxos d'água subsuperficiais ao longo dos eixos das concavidades, aumentando a poro-pressão a jusante e na face de exfiltração junto as bordas dos canais, de modo a ativar a erosão regressiva do canal tal como é observado no Anfiteatro Bela Vista.

A segunda etapa refere-se à fase posterior da remoção dos depósitos de encosta e exumação do saprolito, e conseqüente exfiltração dos fluxos artesianos através do fraturamento subvertical no fundo do canal erosivo, quando os limiares internos acima indicados perdem importância para as relações de vizinhança com os vales de cabeceiras adjacentes, particularmente no que diz respeito à competição pela fonte de água subterrânea que alimenta os fluxos ascendentes (artesianos) e a descarga na face de exfiltração. A maior eficiência da descarga dos fluxos artesianos, aliados à formação preferencial e maior disponibilidade de solos nas proximidades das fraturas funcionais, promoveria o aumento da vulnerabilidade erosiva nos vales de cabeceira. Neste contexto, assim como no desenvolvimento de canais e vales de cabeceiras em separado da rede regional, é a relevante a interação dos processos químicos com os processos físicos que responde pela evolução das cabeceiras de drenagem.

$\mathrm{Na}$ terceira etapa com o aprofundamento e avanço regressivo dos canais sobre as encostas traseiras e mais íngremes das cabeceiras de drenagem, os movimentos gravitacionais de solos, ou deslizamentos, tornam-se mais relevantes no recuo dos divisores, assim como os mecanismos erosivos subseqüentes de erosão por ação direta das chuvas e especialmente do escoamento superficial. Neste caso, as chuvas locais alimentam diretamente a remoção dos materiais colapsados, favorecendo o retro-avanço dos deslizamentos e, por conseguinte, o recuo dos divisores. Os aqüíferos suspensos, por sua vez, podem tornar-se preponderantes na definição de superfícies de rupturas, em associação, principalmente, aos saprolitos de gnaisses bandados, envolvendo possíveis relações com as chuvas locais e/ou com as chuvas regionais. As chuvas regionais seriam responsáveis pela geração das superfícies de rupturas associadas ao nível freático do aqüífero regional, especialmente nos casos de pirataria de água subterrânea entre vales fluviais paralelos e desnivelados entre si.

\section{Conclusões}

Conclui-se que a evolução das cabeceiras de drenagem pode ser modelada a partir da integração dos processos químicos e físicos responsáveis pela formação e denudação dos regolitos. Dentre as conexões mais relevantes para tal, destacam-se as estreitas relações entre os condicionantes litológicos e estruturais na configuração morfológica da superfície estudada no médio vale do rio Paraíba do Sul, e mais especificamente na bacia do rio Bananal. Nesta verifica-se a forte interação dos processos geomorfológicos com o comportamento dinâmico dos aqüíferos subterrâneos, suspensos e locais ou nivelados ao aqüífero principal da bacia (regional), variando de acordo com os estágios evolutivos de uma forma específica ou característica, denominada de concavidade estrutural (CE) e freqüentemente nos vales de cabeceiras do SE do Brasil. Estas evoluem linear e regressivamente, promovendo, de um lado o rebaixamento dos níveis de base locais e do aqüífero subterrâneo, pelo menos em sua área de influencia direta e, de outro, o recuo das encostas a montante e o rebaixamento dos divisores.

A evolução regressiva dos canais incisos (no caso, através do voçorocamento), que constituem as bifurcações externas da rede regional de canais, assim como o rebaixamento progressivo dos canais incisos (também do tipo voçoroca) que se originam em separado, próximo aos divisores de águas, tende a promover a interconexão entre ambos. Este modelo se aproximaria do modelo proposto por Glock (1931), o qual prevê que a extensão da rede de canais se daria pelo avanço remontante dos canais ou pela adição de canais que se originam em separado, até atingir uma extensão máxima sobre toda área de drenagem disponível; para este autor, o rebaixamento dos divisores e a conseqüente redução do relevo promoveriam o desaparecimento de alguns canais por absorção.

Apenas num aspecto o modelo aqui apresentado se diferencia desse modelo, embora o alongamento dos canais na bacia do rio Bananal e adjacências também seja dominante na subdividisão das áreas de drenagem não dissecadas: ele não segue um padrão dendrítico em decorrência do papel relevante das estruturas geológicas subjacentes, particularmente das fraturas subverticais funcionais que regulam as variações espaciais e temporais dos fluxos artesianos associados ao aqüífero regional.

Sobre a idéia de Glock de que o rebaixamento dos divisores e a conseqüente redução do relevo levariam alguns canais a desaparecerem por absorção, pode-se constatar na bacia do rio Bananal que, de fato, durante os períodos de instabilidade morfo-dinâmica, como detectada na transição Pleistoceno-Holoceno, o excedente de sedimentos erodidos nas encostas promove o empilhamento de espessos pacotes sedimentares (agradação dos fundos de vales), causando a absorção dos canais de ordem hierárquica inferior. Este fato já havia sido indicado com base em estudos morfo-estratigráficos no Planalto Sudeste Brasileiro por Meis \& Monteiro, (1979); Meis \& Moura (1984) dentre os principais, que indicam que o preenchimento dos fundos de vales das cabeceiras de drenagem (complexos de rampas) é decorrente da acumulação de colúvios e alúviocolúvios, principalmente derivados do recuo dos 
divisores e coalescência de rampas adjacentes.

Mais recentemente, as datações absolutas dos pacotes sedimentares (de encosta e fluvial), confirmaram que este ciclo de instabilidade erosivadeposicional foi sincronizado no interior da bacia do rio Bananal, durante 2.000 anos, até o sistema de drenagem atingir um novo ajuste interno e estabelecerse em estado estacionário, o qual durou 8.000 anos (Coelho Netto, 1999).

Uma nova mudança na direção evolutiva do sistema da bacia do rio Bananal, em torno de 200 anos atrás, foi induzida por sucessivas substituições de uso e ocupação dos solos, em detrimento da preservação dos remanescentes de Floresta Atlântica. Durante o século XX, assim como nos dias atuais, a devastação da cobertura florestal aliada ao crescimento das metrópoles na região sudeste têm provocado mudanças no regime de distribuição de chuvas locais e regionais, como atestam os estudos mais recentes de Figueiró e Coelho Netto (2003 e 2004).

Estas mudanças climáticas em âmbito regional e local, provavelmente, também são potencializadas pelas mudanças climáticas globais associadas à elevação de temperaturas. Desta forma, hoje se configura uma condição extrema de instabilidade morfo-dinâmica, marcada pela associação entre chuvas intensas, rarefação de vegetação florestal e uso degradante dos solos, que modificam sensivelmente os limiares internos e externos do sistema de drenagem da bacia do rio Bananal e adjacências.

Se por um lado o sistema opera sincronizado em escala de bacia durante os ciclos de instabilidade morfo-dinâmica e na escala de tempo geológico, por outro, ele conduz suas operações internas como produto das relações entre condicionantes locais (ex. fraturas subverticais) e condicionantes regionais (aqüífero subterrâneo), os quais interagem na escala de bacia, tal como evidenciam as maiores concentrações de concavidades estruturais nas porções média-inferior e inferior do vale principal. Portanto, o sistema opera diferencialmente em escala local, e também em escala de bacia, na medida em que a efetividade erosiva e o recuo da rede de canais /cabeceiras de drenagem são controlados por condições locais do fraturamento. Tais condições afetam a funcionalidade hidrológica associada à dinâmica dos aqüíferos artesianos, suspensos e locais, ou de extensão regional; estes operam a denudação na escala da bacia principal, que, por sua vez, estão sob influência hidro-climática regional.

Embora o sistema opere sincronizadamente nas fases de instabilidade do sistema da bacia de drenagem, espacialmente ele não opera de modo uniforme, pois os processos de denudação intensificam-se vale abaixo, tal como evidenciam as maiores concentrações de concavidades estruturais no médio-baixo vale da bacia, o que significa que a denudação dos vales de cabeceiras de drenagem é menos evoluída nas áreas de montante da bacia do rio Bananal, evidenciando uma redução progressiva dos processos erosivos conduzidos pelos fluxos d'água artesianos em fraturas subverticais e alimentados pelo aqüífero regional. Os casos localizados no domínio pré-montanhoso, como na sub-bacia do rio Fortaleza, resultam mais de controles lito-estruturais locais e associados a aqüíferos suspensos alimentados por chuvas locais.

Nessa escala verificou-se que as variações litológicas, por mais sutis que pareçam, impossíveis de serem mapeadas em escala 1:10000, podem ser suficientemente relevantes para definir o confinamento de aqüíferos suspensos, como vistos na sub-bacia do alto rio Fortaleza. Porém, o fato é que ainda pouco se conhece sobre a dinâmica dos aqüíferos subterrâneos no domínio das cabeceiras de drenagem, apesar deste conhecimento ser fundamental para o entendimento dos processos geomorfológicos, seja no domínio montanhoso, de colinas sobre regolitos associados às rochas précambrianas ou em bacias sedimentares terciárias.

Também se torna cada vez mais evidente a necessidade de um maior conhecimento sobre os condicionantes e mecanismos dos processos químicos que regulam a formação diferencial dos regolitos, bem como suas relações com a denudação química e geração de formas depressionárias fechadas. Hoje, essas depressões estão sendo observadas e descritas sob diferentes condições litológicas, tendo uma relação comum com as fraturas subverticais, e vem sendo apontadas como estágio evolutivo inicial dos vales de cabeceiras, em particular no vale do rio Paraíba do Sul.

Enquanto Felizola \& Boulet (1996) enfatizam a denudação química na formação e evolução dos anfiteatros de cabeceiras de drenagem, Castro e Coelho Netto (2002) apresentam que as depressões fechadas podem ser vistas também como protovales, ou seja, como formas que poderiam ter evoluído como vales de cabeceiras de drenagem, mas que foram interrompidos. Por outro lado, as evidências de estágios mais avançados de intemperismo no entorno de fraturas permite supor que a maior disponibilidade de regolito também favorece a abertura e evolução das cabeceiras por ação mecânica.

$\mathrm{Na}$ realidade, os processos químicos e mecânicos não são excludentes entre si, mas resta saber a magnitude dos diferentes processos nos diferentes estágios da evolução do modelado, tanto nas cabeceiras de drenagem como nas suas bacias principais. Haveria um estágio crítico em que ocorreria uma mudança na relevância destes processos? Seria este estágio crítico de mudança, variável entre domínios montanhosos ou de colinas, em substrato rochoso pré-cambriano, ou domínios de bacias sedimentares em substrato sedimentar terciário? São questões que permanecem em aberto até 
que se possa avançar nas pesquisas geomorfológicas sob diferentes condições lito-estruturais e hidrológicas ocorrentes.

Em síntese, pode-se afirmar que a expansão regressiva da rede de canais é descontínua no tempo e no espaço, sendo governada por relações funcionais que regulam a dinâmica dos aqüíferos subterrâneos e os processos conjuntos de denudação química e mecânica. Tal expansão envolve mudanças externas, climáticas e/ou vegetacionais, traduzidas nas variações da infiltração e recarga dos aqüíferos e envolve também os limiares internos do sistema de drenagem, os quais podem ser ultrapassados por mecanismos de retroalimentação positiva.

Esta retroalimentação envolve o rebaixamento do nível de base pela progressão linear e remontante da incisão dos canais erosivos (voçorocas) ou ainda pelo recuo de divisores e capturas de drenagem dos vales fluviais suspensos em relação aos vales capturados, como conseqüência da pirataria de água subterrânea do vale capturado.

Os períodos transitórios de mudanças da cobertura vegetal, em associação com os períodos mais chuvosos contendo eventos extremos de chuvas, seriam os mais críticos em termos de intensidade erosiva por meio de avanço regressivo da rede de canais. Nos dias atuais o que prevalece é uma paisagem regional instável e heterogênea, submetida a mudanças ambientais cada vez mais rápidas e altas taxas de erosão e deposição, nas encostas e fundos de vales fluviais, que por sua vez tendem a potencializar a vulnerabilidade das encostas tornando-as mais suscetíveis ao desencadeamento de processos erosivos de alta magnitude, intensificando a ocorrência de desastres naturais relacionados à água.

\section{Agradecimentos}

A autora é grata à Revista Brasileira de Geomorfologia-UGB que através de sua atual editorachefe me estimulou a rever os estudos, idéias e reflexões geomorfológicas acumuladas nos últimos vinte e poucos anos; agradeço e dedico este trabalho aos meus ex-e atuais alunos e demais parceiros citados neste trabalho, com os quais muito partilhei e aprendi sobre as cabeceiras de drenagem. Um agradecimento especial aos colegas André de Souza Avelar e Selma Simões de Castro pela revisão crítica deste trabalho, clareando e introduzindo melhorias no texto e também pela parceria em etapas da pesquisa. Minha homenagem aos amigos e parceiros especiais de idéias e trabalhos conjuntos ao longo de minha jornada geomorfológica, M. Regina Mousinho de Meis (in memorian), Jan De Ploey (in memorian), William E. Dietrich. Ao CNPq-Conselho Nacional de Desenvolvimento Científico e Tecnológico e a FAPERJ-Fundação Carlos Chagas de Amparo a Pesquisa do Estado do Rio de Janeiro, meus principais órgãos de fomento ao longo de todos estes anos, a minha gratidão.

\section{Referências bibliográficas}

Ahnert, F. (1998) Introduction to Geomorphology. Ed by Arnold, London: 352 p.

Almeida, J.C.H.; Silva, L.G.E.; Valeriano, C. \& Heilbron, M. (1999) Structural framework and landscap evolution between Bocaina and Mantiqueira ranges, Southeastern Brazil, Proceed. IGU- GERTEC Meeting on Geomorphic Responses to Vegetation Changes Proc..

Almeida, J.C.H; Silva ,L.G.E \& Avelar,A.S. (1991) "Coluna tectono-estratigrafica de parte do complexo Paraíba do Sul, na região de Bananal/SP”, Simp. Geol. Sudeste - 2, São Paulo - Anais - SGB: 509-5127.

Almeida, J.C.H.; Silva, L.G.E. \& Valladares, C.S. (1993) "O Grupo Paraíba do Sul e as Rochas Granitóides na Região de Bananal (SP) e Rio Claro (RJ): uma proposta de formalização litoestratigráfica. Simp. de Geologia do Sudeste 3, RJ.

Avelar, A.S. e Coelho Netto, A.L. (1992a) Fraturas e desenvolvimento de unidades geomorfológicas côncavas no médio vale do rio Paraíba do Sul;Rev. Bras. Geociências,vol. 22 n.2:222-227.

Avelar, A.S. e Coelho Netto, A.L. (1992b) Fluxos d'água subsuperficiais associados a origem das formas côncavas do relevo. Anais da 1a. Conferência Brasileira de Estabilidade de Encostas /COBRAE, ABMS e SBGE, Rio de Janeiro; vol.2:709-719.

Cambra, (1998) Movimentos de água na porção superior de solos sob pastagem: o papel do sistema radicular. Dissertação de Mestrado, Departamento de Geografia, UFRJ p. 144.

Castro, S.S. e Coelho Netto, A. L. (2002) Evolução pedogenética em depressão de topo, na bacia do alto rio Fortaleza, região de Bananal (SP/RJ): resultados preliminares. Anais, IV Enc. Eng. Geotécnica e Hidrologia no Sistema Encosta-Planície Costeira/PRONEX-Projeto no 14/97; Publ. Organizado por Coelho Netto, A.L. e Lacerda, W.A.: 181-192.

Coelho Netto, A.L.; Fernandes, N.F. And Deus, C.E. (1988) Gullying in the southeastern Brazilian Plateau, Bananal, S.P. in: Sediment Budgets, Edited by M.R. Bordas e D.E. Walling; IAHS Publ. n.174:35-42.

Coelho Netto, A.L. \& Fernandes, N.F. (1990) Hillslope erosion - sedimentation and relief inversion in Bananal,SP; Proceedings Intern. Symp. on "Research Needs and Applications to Reduce Erosion \& Sedimentation in Tropical Steeplands",Suva,Fiji; IAHS Publication, $\mathrm{n}^{\circ}$ 192: 
Coelho Netto, A.L.; Fernandes. N.F.; Dantas, M.E.; Dietrich, W.E. Montgomery,D.; Davis. J.C.. Proctor, I. Voggel, J. And Southon, J. (1994) ${ }^{14} \mathrm{C}$ AMS evidences of two Holocene erosionsedimentation cycles in SE Brasil: stratigraphy and stratigraphic inversions; 14th Intern. Sedimentary Congress, IAS-Internat. Association of Sedimentologists, Recife: 2830.

Coelho Netto, A.L. (1997) Voçorocamento na bacia do rio Bananal. $\mathrm{CD}$ do Congresso Brasileiro de Solos, no Rio de Janeiro.

Coelho Netto, A L. (1999) Catastrophic Landscape Evolution in a Humid Region (SE Brazil): inheritances from tectonic, climatic and land use induced changes. Supplementi di Geografia Fisica e Dinamica Quaternária, Supp. III, Tomo 3: 21-48.

Coelho Netto, A.L. (2002) Água subterrânea, mecanismos de erosão e evolução de cabeceiras de drenagem na região sudeste brasileira: importância da pesquisa na interface geológica-geomorfológicageotécnica; Anais, IV Enc. Eng. Geotécnica e Hidrologia no Sistema Encosta-Planície Costeira/PRONEX-Projeto $\mathrm{n}^{\circ}$ 14/97; organizado por Coelho Netto, A.L. e Lacerda, W.A.: 17-21.

Dantas \& Coelho Netto, (1994) Spatially non-uniform sediment storage in fluvial systems: the role of bedrock knickpoints in the southeastern brazilian plateau; 14th Intern. Sedimentary Congress, IAS-International Association of Sedimentologists, Recife, p. 12-13.

Dantas, (1995) Controles naturais e antropogênicos na sedimentação fluvial, espacialmente não uniforme, na bacia do rio Bananal $(\mathrm{SP} / \mathrm{RJ})$ : Médio Vale do rio Paraíba do Sul ; (Mestrado) PPGG/UFRJ. Dissertação e Mestrado, Departamento de Geografia, UFRJ.

Deus, C. E. (1991) O papel da formiga Saúva (Gênero ATTA) na hidrologia e erosão dos solos em ambiente de pastagem: Bananal, SP". Tese de Mestrado, PPGG-UFRJ.

Dietrich, W.E. \& Dunne, T. (1993) The channel head. In: Beven, K. \& Kirkby, M.J. (eds), Channel Network Hydrology, John Wiley \& Sons, Chinchester: 175-219.

Dietrich. W.E.; Montgomery. D. ; Coelho Netto, A.L. \& Moura, J.R.S. ( 1991) Evidence for regional aggradation starting in the Early Holocene in southeastern Brazil and for degradation due to deforestation. Am. Geoph.Union, Fall Meet., San Francisco,USA/EOS, vol. 70(43):1124.

Dietrich, W.E.; Wilson, C.J.\& Reneau, S.L. (1986) Hollows, colluvium and landslides in soilmantled landscapes. In: Abrahams, A.D. (ed.),
Hillslope Processes, Winchester, Mass., Allen \& Unwin Inc: 361-388.

Dunne, T. (1970) Runoff production in a humid area. US Department of Agriculture ReportARS 41160.

Dunne, T. (1980) Formation and controls of channel networks. Prog. Phys. Geogr. 4,211-239.

Dunne, T. (1990) Hydrology, mechanics and geomorphic implications of erosion by subsurface flow. In HigginsC.G. \& Coates, D.R. (Eds), Groundwater Geomorphology, Geol. Soc. Am. Sp. Paper 252: 1-28.

Felizola, H. F. \& Boulet, B. (1993) Une évaluation de la vitesse de l'érosion géochimique à partir de l'étude de dépressions fermées sur roches sédimentaires quartzo-kaoliniques au Brésil. C.R. Acad. Sci. Paris, 316, sér. II: 693-700.

Felizola, H. F. \& Boulet, B. (1996) Evolution and opening of closed depressions devoloped in a quartz-kaolinitic sedimentary substratum at Taubaté basin (São Paulo, Brazil), and analogy to the slope evolution. Geomorphology 16 (1996) 77-86.

Fernandes, N.F. (1991) Hidrologia subsuperficial e propriedades fisico-mecânicas dos complexos de Rampa-Bananal (SP), M.Sc. Thesis, Universidade Federal do Rio de Janeiro, 151 pp.

Figueiró, A. \& Coelho Netto, A.L. (2003)Do Local ao Regional: análise comparativa de transectos pluviométricos em diferentes escalas; V Encontro Nacional da Associação Nacional de Pós Graduação em Geografia/ANPEGE, Florianópolis.

Leite, A.F. \& Coelho Netto, A.L. (2004) Rotas de fluxos hidrogeoquímicos em uma pequena bacia montanhosa rural: alto Vale do Rio Fortaleza, Bananal (SP). X SINAGEO, Santa Maria (no prelo).

Fonseca, A.P.; Santos, R.M. \& Lacerda, W.A. (2002) Voçorocamento asociado a escorregamento em Três Barras, Bananal, SP. Anais, IV Enc. Eng. Geotécnica e Hidrologia no Sistema Encosta-Planície Costeira/PRONEX-Projeto nº14/97; organizado por Coelho Netto, A.L. e Lacerda, W.A.: 17-21.

Freitas, M.M.; Patrício, R.S.S. \& Coelho Netto, A.L. (1995) Condicionantes morfológicos e litoestruturais da iniciação de canais, médio vale do rio Paraíba do Sul, Bananal, SP. Anais, VI Simpósio Nacional de Geografia Física Aplicada, Goiânia, vol 1:222-227.

Gilbert, K.G. (1877) Report on the geology of the Henry Mountains (Utah). U.S.Geogr. Geol. Survey Rocky Mtn. Region (Powell): 18-98.

Glock, W.S. (1931) The development of drainage systems: a synoptic view. Geogr.Rev.21:475482. 
Hack, J. T. (1960) Interpretation of erosional topography in Humid Temperate regions. American Journal of Science, 188, p 80-97.

Heilbron, M. (1995) O Segmento Central da Faixa Ribeira: síntese geológica e ensaio de evolução geotécnica. Tese de Livre Docência. DGEL/UERJ, p. 110.

Horton, R. (1945) Erosional development of streams and their drainage basins: hydrophysical approach to quantitative Geomorphology. Geol.Soc.Am.Bull.56:275-370.

Howard, A.D. (1971) Simulation of stream network by headward growth and branching. Geogr. Anal. 3:29-50.

Kirkby, M.J. (ed.) (1994) Process, models and theoretical Geomorphology, Chichester, John Wiley \& Sons.

Lafayete, R.P., Barreto, A.A.L.M., Bronz, D. \& Coelho Netto, A.L. (1998) Mapeamento de concavidades nas encostas da bacia do rio Bananal, médio vale do rio Paraíba do Sul (SP/RJ). GEOSUL, Florianópolis, vol. 14(27): 633-636.

Leal, P. V. (2004) Relação entre fluxos subterrâneos de vales vizinhos e a expansão da rede de drenagem via voçorocamentos na Bacia do Rio Piracema, Bananal SP. Dissertação de Mestrado, Programa de Pós-Graduação em Geografia, UFRJ.

Machado, M.B. \& Moura, J.R.S. (1982) A Geomorfologia e a sedimentação Quaternária no médio vale do rio Casca, MG. Anais, Congr. Bras. Geologia, Salvador, vol.4: 1433-1441.

Meis, M.R.M. \& Monteiro, A.M.F. (1979) Upper Quaternary rampas: Doce river valley, SE Brazilian Plateau. Zeit. Geomorph., 23: 132151.

Meis, M.R.M. \& Moura, J.R.S. (1984) Upper Quaternary sedimentation and hillslope evolution SE Brazilian Plateau. Am. Jour. Sc., 281:241-254.

Meis, M. R. M. ;Coelho Netto, A.L \& Oliveira, P.T (1981) Rítmo e variabilidade das precipitações no Vale do Rio Paraíba do Sul: o caso de Resende; Revista Brasileira de hidrologia e Recursos Hídricos vol. 3 p. 1489-1503.

Mello, C.L. (1992) Fácies sedimentares, arquitetura deposicional e relações morfoestratigráficas em um sistema de leques aluviais holocênicos: aloformação Manso, médio vale do rio Paraíba do Sul (SP/RJ). Dissertação de Mestrado, Departamento de Geologia, UFRJ: 188p.

Montgomery, D.R. \& Dietrich, W.E. (1989) Source areas, drainage density and channel initiation. Water Resources Research, 26:1907-1918.

Moura, J.R.S. (1991) Transformações ambientais durante o Quaternário Tardio no médio vale do rio Paraíba do Sul (SP-RJ). Tese de Doutorado, Depto. de Geografia, UFRJ:267 p.

Moura, J.R.S. \& Meis, M.R.M. (1986) Contribuição a estratigrafia do Quaternário Superior no médio vale do rio Paraíba do Sul Bananal, SP. Anais, Acad. Bras. de Ciências, Rio de Janeiro, 58:89102.

Moura, J.R.S.; Peixoto, M.N.O.\& Silva, T.M. (1991) Geometria do relevo e estratigrafia do Quaternário como base a tipologia de cabeceiras de drenagem em anfiteatro, médio vale do rio Paraíba do Sul. Ver. Brás. Geociências, São Paulo, 21(3): 255-265.

Oliveira, M.A.T. \& Meis, M.R.M. (1985) Relações entre a geometria do relevo e formas de erosão linear acelerada, Bananal, SP. Geociências, São Paulo, 4: 87-99.

Pederson, D. T. (2001) Stream Piracy Revisited. GSA TODAY, Vol. 11, n'9: 4-10.

Riccomini, C. (1989) O rift continental do Sudeste do Brazil. Tese de Doutorado, IG-USP, p. 256.

Rocha-Leão, O.M.; Moraes Silvaa, T.R.; Leal, P., Lacerda, W.A. \& Coelho Netto, A.L. (2001) Relações entre propagação de voçorocamentos em cabeceiras de drenagem e movimentos de massa em divisores topográficos, Bananal, SP. Anais, III COBRAE/ABMS-RJ:141-149.

Rocha-Leão, O.M.; Leal, P.V. e Coelho Netto, A.L. (2003) Condicionantes geo-hidroecológicos de voçorocamentos em cabeceiras de drenagem, Bananal-SP; X Simp. Brás. de Geografia Física Aplicada, Rio de Janeiro.

Rocha-Leão, O. M. - Propagação remontante e controle de voçorocas em formações quaternárias no Médio Vale do rio Paraíba do Sul - Bananal, SP: potencialidades e limitações da revegetação no controle da erosão. Tese de Doutorado (em preparação).

Silva, L. G. E.; Dantas, M.E. \& Coelho Netto, A.L. (1993) Condicionantes litoestruturais na formação de nineis de base locais ("knickpoints") e as implicações geomorfológicas no vale do rio Paraíba do Sul (RJ/SP). Anais, III Simpósio de Geologia do Sudeste, Rio de Janeiro, SBG, vol.3: 96-101.

Strahler, A. (1952) Hypsometric (área-altitude) analysis of erosional topography. Geol.Soc. of Am Bull., 63: 1117-1142.

Valeriano, C. M. \& Heilbron, M. (1993) A zona de transtensão de Volta redonda e sua implicação na compartimentação tectônica da porção central da faixa Ribeira, In: Simpósio de geologia do Sudeste, 3. Rio de Janeiro. Atas SBG.: 9-15.

Xavier, R.A., Leite, A. F. \& Coelho Netto, A.L. (2002) Fraturas e artesianismo como condicionantes do intemperismo diferencial na bacia do alto 
rio Fortaleza, Bananal/SP: evidências mineralógicas. $10^{\circ}$ Congr. Bras. Geologia de Engenharia e Ambiental. Ouro Preto - MG

Xavier, R.A. (2004) Fraturas e intemperismo diferencial no controle da evolução de cabeceiras de drenagem: bacia do rio bananal, SP-RJ. Dissertação de Mestrado, Programa de Pós-Graduação em Geografia, UFRJ. 